\title{
Diversity, rarity and the evolution and conservation of the Canary Islands endemic flora
}

\author{
by \\ J. Alfredo Reyes-Betancort ${ }^{1}$, Arnoldo Santos Guerra ${ }^{1}$, I. Rosana Guma ${ }^{1}$, \\ Christopher J. Humphries ${ }^{2} \&$ Mark A. Carine $e^{2,3}$ \\ ${ }^{1}$ Unidad de Botánica Aplicada, Instituto Canario de Investigaciones Agrarias, Jardín de Aclimatación de La Orotava, \\ c/ Retama n. ${ }^{\circ}$ 2, 38400 Puerto de La Cruz, Santa Cruz de Tenerife, Spain \\ ${ }^{2}$ Department of Botany, The Natural History Museum, Cromwell Road, London SW7 5BD, United Kingdom \\ ${ }^{3}$ Author for correspondence: m.carine@nhm.ac.uk
}

\begin{abstract}
Reyes-Betancort, J.A., Santos Guerra, A., Guma, I.R., Humphries, C.J. \& Carine, M.A. 2008. Diversity, rarity and the evolution and conservation of the Canary Islands endemic flora. Anales Jard. Bot. Madrid 65(1): 25-45.

The endemic vascular flora of the Canary Islands comprises over 680 , taxa collectively accounting for more than $50 \%$ of the total native flora. To investigate geographical patterns of diversity within the endemic flora, distribution data from published sources together with other field observation and herbarium data were used to compile a data matrix comprising the distributions of ca. $90 \%$ of endemic taxa scored on a $10 \times 10 \mathrm{~km}$ UTM grid. WORLDMAP was then used to investigate patterns of endemic diversity, range size rarity (a measure of endemicity), phylogenetic diversity and threatened taxon richness. Endemic taxon richness was found to be highly heterogeneous across the archipelago, with cells containing between one and 139 taxa each $(0.05-22.82 \%$ of endemic diversity). Patterns of variation in range size rarity and phylogenetic diversity were found to be largely congruent with endemic diversity, although some cells exhibited markedly higher range size rarity scores than would be predicted by their endemic diversity scores. In contrast, the pattern of endangered taxon richness across the archipelago differed markedly from endemic taxon richness. Many cells in Lanzarote, Fuerteventura and Gran Canaria exhibit higher endangered taxon richness scores than would be predicted from their endemic richness scores whereas in Tenerife, El Hierro, La Palma and La Gomera, the converse is generally true. The implications of the results both for understanding the evolution of Canary Island endemic diversity and for the conservation of the region's unique and vulnerable flora are considered.
\end{abstract}

Keywords: Canary Islands, endemism, species richness, range size rarity, threatened species richness, phylogenetic diversity, evolution, conservation.

\section{Resumen}

Reyes-Betancort, J.A., Santos Guerra, A., Guma, R., Humphries, C.J. \& Carine, M.A. 2008. Diversidad, rareza, evolución y conservación de la flora endémica de las Islas Canarias. Anales Jard. Bot. Madrid 65(1): 25-45 (en inglés).

La flora vascular endémica de las Islas Canarias comprende unos 680 táxones, lo que viene a representar más del $50 \%$ de la flora nativa. Con objeto de investigar patrones geográficos de diversidad en la flora endémica, se recopilaron los datos publicados que, junto con otras observaciones de campo y datos de herbario, sirvieron para completar una matriz de datos que abarca la distribución de cerca del $90 \%$ de los táxones endémicos usando cuadrículas UTM de10 $\times 10 \mathrm{~km}$. A continuación, se utilizó el programa WORLDMAP para investigar los patrones de diversidad de los endemismos, el rango del grado de rareza (una medida de endemicidad), la diversidad filogenética y la riqueza en táxones amenazados. Se observó que la riqueza en endemismos es muy heterogénea a lo largo del archipiélago, con unos valores por cuadrícula que oscilan entre 1 y 139 táxones $(0,05-22,82 \%$ de la diversidad de táxones endémicos). Los patrones de variación del rango del grado de la rareza y la diversidad filogenética resultaron ser en gran parte congruentes con la diversidad en endemismos, aunque algunas cuadrículas mostraron valores mucho más altos de rareza de los que podían ser predichos dada su diversidad de endemismos. En contraste, los patrones de riqueza en especies amenazadas en el archipiélago difirieron marcadamente de la riqueza en táxones endémicos. Muchas cuadrículas de Lanzarote, Fuerteventura y Gran Canaria mostraron valores más altos de riqueza en especies amenazadas que las que pudieran ser predichas sobre la base de su riqueza en táxones endémicos, mientras que en Tenerife, El Hierro y La Gomera la regla fue generalmente lo contrario. Se consideran las implicaciones que estos resultados suponen para la comprensión de la evolución de la diversidad de endemismos canaria y para la conservación de su singular y vulnerable flora.

Palabras clave: Islas Canarias, endemismo, riqueza en especies, rango del grado de rareza, riqueza en especies amenazadas, diversidad filogenética, evolución, conservación. 


\section{Introduction}

The Canary Islands archipelago comprises seven main islands together with a number of smaller islets located off the northwest coast of Africa (Fig. 1). According to the most recent biogeographic classification scheme (Rivas-Martínez, 2007), the Canary Islands are recognised as a biogeographic province within the Canario-Madeirense Subregion (Mediterranean Region), with two sub-provinces distinguished: the Eastern Canaries (Lanzarote and Fuerteventura, and the Salvage Islands of Portugal) and the Western Canaries (Gran Canaria, Tenerife, La Gomera, La Palma and El Hierro).

The endemic flora of the Canary Islands is extremely rich, with over 680 endemic taxa currently recognised (species and subspecies), collectively accounting for more than $50 \%$ of the total native flora (Santos-Guerra, 2001). The Canary Islands are considered as a hotspot of plant diversity within the Mediterranean global diversity hotspot (Quézel \& Médail, 1995) and the high levels of endemicity observed in both the Canary Islands flora and fauna led Sundseth (2005) to describe the archipelago as one of the top biodiversity hotspots in the world.

The distribution of endemic diversity within the Canary Islands is heterogeneous. Many endemics are extremely restricted in their distribution and a number of areas have been identified that exhibit a concentration of highly localised endemics (Bramwell \&
Bramwell, 2001). Emerson \& Kolm (2005) demonstrated a close correlation between the number of single island endemics and the total number of species per island and proposed that 'diversity begets diversity' i.e. that higher species richness on islands is a driver for higher rates of diversification. Other authors have challenged this explanation for the observed pattern, suggesting that species diversity and endemicity co-vary because abiotic factors influence both in a similar manner (e.g. Pereira \& al., 2007). Whittaker \& al. (2007) proposed an alternative model to explain the heterogeneity of the flora in which both species richness and speciation rate reach a maximum when an island reaches maximum topographic complexity. To date, however, such analyses have focussed on between-island comparisons and have not taken into account the considerable within-island heterogeneity in endemic species richness. Knowledge of such intra-island patterns of diversity could conceivably shed further light onto the ecological-evolutionary mechanisms promoting diversification of the region's flora.

From a conservation perspective, the Canary Islands endemic flora is highly vulnerable to environmental change, especially the disruptive and destructive alteration brought about by human interference and invasive species (Bramwell, 1990). Two hundred and eleven endemic spermatophytes representing more that $30 \%$ of the endemic flora, are currently included on the Canary Islands red list (Go-

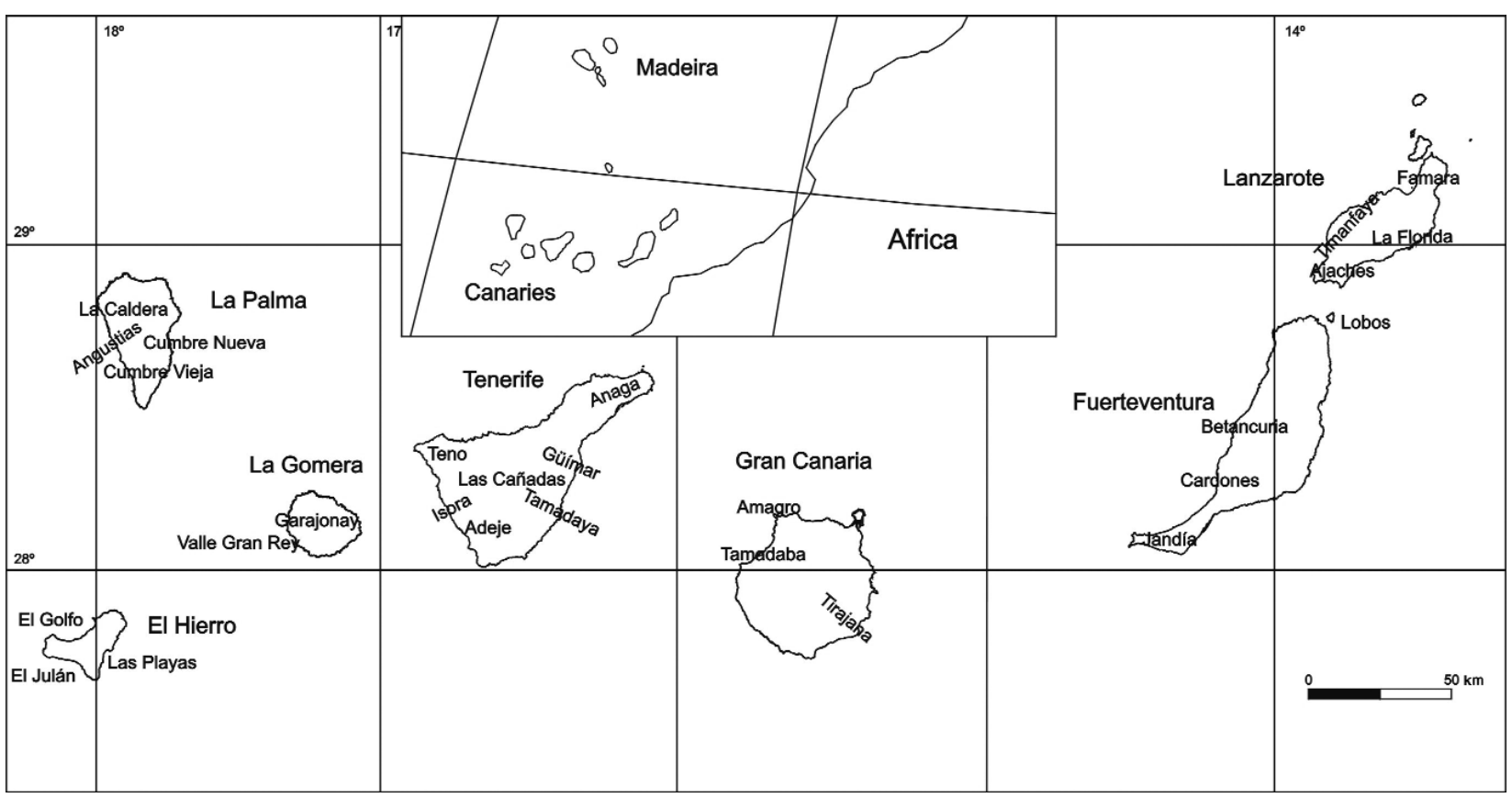

Fig. 1. The Canary Islands and the approximate location of some of the major geographical features in the archipelago discussed in the text. 
bierno de Canarias, 2000) of which 168 (23\% of the endemic flora) are included in the Atlas y Libro Rojo de la Flora Amenazada de España (Bañares \& al., 2004) that covers all of Spain. In order to conserve the unique and threatened flora, vegetation, landscapes and culture of the Canary Islands, an extensive network of protected areas has been developed. A total of 146 protected areas have been designated, covering approximately $40 \%$ of the archipelago's total area (Gobierno de Canarias, 2001; see http://www. gobcan.es/cmayot/espaciosnaturales/categorias/ ase.html).

However despite the importance and vulnerability of the Canarian flora and the extent of the protected area network, explicit analyses of geographical patterns of diversity within the flora have been extremely limited. Gaisberg \& Stierstorfer (2005) investigated patterns of taxon richness and diversity within $\mathrm{El}$ Hierro and demonstrated that whilst endemic diversity is highest on geologically old surfaces, diversity of the total flora (including the introduced flora) generally increases with precipitation and human impact. Del-Valle \& al. (2004) analysed the distributions of taxa listed in Bañares \& al. (2004) to delimit Important Areas for the Endangered Flora (hereafter abbreviated to IPAs) within Spain. The distributions of taxa analysed were recorded on a $1 \times 1 \mathrm{~km}$ UTM grid and taxa were given differential weights depending on their threat status with more threatened taxa receiving higher weight. Of the 30 highest ranked areas identified in the analysis, 22 were located in the Canary Islands with the Teno massif of Tenerife (Fig. 1) ranked first overall. Del-Valle \& al. (2004) did not explicitly analyse congruence between the current protected area network and IPAs, but it is notable that Teno, is currently protected by a Parque Rural, a relatively low level of protection. It would therefore appear that there is an imperfect fit between vulnerability and degree of protection in the Canary Islands. Further studies to better understand the underlying patterns of biodiversity distribution in the archipelago are necessary to determine the effectiveness of the protected area network for conserving diversity.

Whilst the need to understand geographical patterns of biodiversity to support the development of effective protected area networks is now widely acknowledged (Lamoreux \& al., 2006; Langhammer \& al., 2007), this task is not straightforward because different biodiversity measures may suggest different priority areas for conservation. This has already been documented for the Canary Islands by Gaisberg \& Stierstorfer (2005) who demonstrated that hotspots of species richness and endemic richness in El Hierro are not coincident. However, their measure of total species richness included the considerable introduced element in the flora that is unlikely to be of interest for conservation purposes. In a global analysis of bird distributions, Orme \& al. (2005) demonstrated that there is only very limited congruence between the priority areas for conservation identified when total species richness, threatened species richness and endemic richness are used. Indeed, only $2.5 \%$ of hotspot areas are common to all three methods. Forest \& al. (2007) recently investigated patterns of taxon richness and phylogenetic diversity in the Cape Biodiversity hotspot and similarly found these two measures to be uncorrelated. Phylogenetic diversity (PD) may be defined as the total length of the evolutionary tree that connects the taxa within a given area (Vane-Wright \& al., 1991; Faith, 1992) and may be considered a measure of 'feature diversity'. Forest \& al. (2007) demonstrated that in the Cape Flora of South Africa, taxon richness is greatest in the Western Cape but the flora of this region has a lower PD score than would be predicted by its taxon richness. In contrast, the flora of the less taxon-rich Eastern Cape has a higher PD score than predicted. Whilst conservation efforts in the Cape region have traditionally focussed on the taxon-rich Western Cape, other areas in the Eastern Cape should also be targeted for conservation if feature diversity is considered an important component of diversity. The results of the analyses of Orme \& al. (2005) and Forest \& al. (2007) demonstrate that whilst congruence between different measures of diversity may exist (e.g. Polasky $\&$ al., 2001), this cannot be assumed, as they are measuring different aspects of diversity. Any one index may not necessarily be considered an effective surrogate for other aspects of diversity and multiple indices of diversity are necessary to identify areas of high conservation priority (Orme \& al., 2005; Forest \& al., 2007).

In this paper, we investigate geographical patterns of diversity within the Canary Islands endemic flora using a dataset comprising the distributions of over 90\% (609 taxa) of the endemic plant taxa of the Canary Islands archipelago. Specifically, our goals are threefold. Firstly, we aim to investigate and describe patterns of endemic richness across the archipelago. Secondly, we investigate the extent to which other measures of diversity, notably range size rarity (a measure of endemicity), phylogenetic diversity and threatened taxon richness, exhibit similar patterns to endemic richness. Thirdly, we consider the implications of these data for our understanding of the mechanisms promoting the evolution of Canary Islands endemic diversity and the conservation of the region's unique and vulnerable flora. 


\section{Materials and methods}

\section{Distribution data}

The following published works were used as initial sources of distribution data for most species: Barquín Díez \& Voggenreiter (1988), Gómez Campo \& al. (1996), Beltrán Tejera \& al. (1999), Bañares \& al. (2004), Stierstorfer \& von Gaisberg (2006) and distributions were scored on a $10 \times 10 \mathrm{~km}$ UTM grid. This grid size was selected because a substantial amount of the distribution data for Canary Islands plants contained in these works is either already scored or is readily amenable to scoring on a grid of this scale. Thus, distribution data in Gómez Campo \& al. (1996) were already scored on a $10 \times 10 \mathrm{~km}$ UTM grid whilst the data provided by Beltrán Tejera \& al. (1999), Bañares \& al. (2004), and Stierstorfer \& von Gaisberg (2006) were scored on a smaller grid that was converted to a $10 \times 10 \mathrm{~km}$ grid for the analysis. Point distribution data provided by Barquín Díez \& Voggenreiter (1988) were converted by overlaying a $10 \times 10 \mathrm{~km}$ grid on the distribution maps and scoring taxa as present in a cell if a point distribution record was present within it. The addition of further data, the checking and verification of distributions and the resolution of mismatches were undertaken by two of us (ASG and JAR-B) based on personal observations of taxa in the field and herbarium material at ORT. The final data matrix is available from the corresponding author on request.

The distributions of all Canary Islands endemic spermatophytes were included in the matrix with the exception of (i) taxa of uncertain taxonomic status (e.g. Taraxacum canariense Soest, Silene canariensis Willd.) and (ii) species that are extremely widespread within the archipelago and consequently have distributions that are difficult to record accurately, even on a $10 \times 10 \mathrm{~km}$ grid scale (e.g. Forsskaolea angustifolia Retz., Kleinia neriifolia Haw.). Excluding these taxa from the analysis, the distributions of 609 endemic Canary Islands spermatophytes (species, and subspecies) were recorded, representing approximately $90 \%$ of the total endemic flora.

\section{Biodiversity measures}

Analyses of geographical patterns of diversity were undertaken using Worldmap 4.20.24 (Williams, 2003), a software package widely used for exploring geographical patterns in diversity, rarity and conservation priorities from large biological datasets (e.g. Castro Parga \& al., 1996; Humphries \& al., 1999; Väre \& al., 2003).

The total number of Canary Islands endemic taxa present in each $10 \times 10 \mathrm{~km}$ cell was recorded and the endemic richness of the cell was the percentage of total diversity it contained. Range size rarity (RSR) for a taxon (or more correctly, inverse range size rarity) is defined as the inverse of the number of cells within which that species occurs. The sum of the range size rarities of taxa occurring within a cell simulates the endemism richness of that cell and this was calculated for each cell in Worldmap using the following expression:

Sum[range size rarity scores for all species in the cell ]

Sum[total range size rarity scores for each cell in the analysis]

Phylogenetic diversity (PD) for each cell was estimated using the method of Vane-Wright \& al. (1991). This method first requires a phylogeny of the taxa included in the analysis and then measures PD by counting the proportion of the total number of nodes represented within each cell. A generic-level phylogenetic classification of the endemic Canary Island flora was used to estimate PD and was constructed as follows:

(i) The ordinal classification provided by the Angiosperm Phylogeny Group (2003) was used to resolve higher-level relationships among genera represented in the Canary Island endemic flora.

(ii) The following published analyses were used to resolve infra-familial generic relationships: AlShehbaz \& al. (2006, Brassicaceae); Albach \& al. (2005, Plantaginaceae); Bremer (1994, Asteraceae excl. Lactuceae); Downie \& al. (2000, Apiaceae); Fior \& al. (2006 Caryophyllaceae); Harley \& al. (2004, Lamiaceae); Helfgott \& al. (2000, Rosaceae); Kadereit \& al. (2003, Amaranthaceae); Kim \& al. (1996, Asteraceae-Lactuceae); Lewis \& al. (2005, Fabaceae); Mort \& al. (2002, Crassulaceae).

(iii) Within those genera for which phylogenetic hypotheses suggests the non-monophyly of the Canary Island endemic congeners (see Carine $\&$ al., 2004; Lledó \& al., 2005), each colonisation group was scored as a separate group in the analysis.

No attempt was made to further represent patterns of relationships within individual genera. This is because the sampling of taxa in phylogenies of Canary Island groups is often inadequate to place all taxa that were included in the present analysis within an infrageneric grouping. Furthermore, resolution within many island groups is either lacking or poorly supported. 
Whilst our overall goal was to provide a fully resolved generic-level classification with infra-generic resolution where there was molecular support for the non-monophyly of the island endemics within a genus, a lack of resolution for basal relationships in some families (e.g. Poaceae; Grass Phylogeny Working Group, 2001) meant that some generic relationships were left unresolved. Furthermore, the constraints of the taxonomic hierarchy permitted by Worldmap that allows only 15 nodes of information per terminal taxon meant that it was not possible to fully represent the resolution of generic-level relationships within Asteraceae (Bremer \& al., 1994) or Lamiaceae (Harley \& al., 2004). Within these two families, it was necessary to exclude one node of information from the classification of the most derived groups. The generic level classification used to examine patterns of Phylogenetic Diversity in Worldmap is summarised in Annex 1.

Threatened taxon diversity (TD) was assessed by restricting the analysis to those spermatophytes that are listed in Bañares \& al. (2004) and that are endemic to the archipelago. In total, Bañares \& al. (2004) listed 167 spermatophyte taxa that occur in the Canary Islands. However, eight are not endemic and were therefore excluded from the analysis (Asteriscus schultzii (Bolle) Pit. \& Proust, Astragalus edulis Bunge, Carex muricata L. subsp. muricata (= C. pairae F.W. Schultz), Dracaena draco L. subsp. draco, Euphorbia mellifera Aiton, Juniperus cedrus Webb \& Berthel., Limonium tuberculatum (Boiss.) Kuntze, Zygophyllum gaetulum Emb. \& Maire) whilst Aeonium mascaense Bramwell is considered extinct in the wild and was also excluded. In total therefore, the distributions of 157 endangered endemic taxa were investigated to establish patterns of threatened species richness. It should be noted that in several instances [e.g. Androcymbium psammophilum Svent.; Convolvulus subauriculatus (Burch.) Linding.] the distributions of endemic taxa scored in the present analysis differed from those given by Bañares \& al. (2004). This reflects the improved knowledge of the distributions of these taxa since that publication.

\section{Correlation of biodiversity values}

The Spearman Rank correlation test was used to measure for correlations between endemic taxon diversity and each of the other three diversity measures (i.e., range size rarity, threatened taxon diversity and phylogenetic diversity). Deviations from the Spearman Rank correlation test were plotted for each cell to further investigate the nature of the correlation in each case.

\section{Complementarity}

Complementarity refers to the degree to which the addition of cells to an existing set of cells contributes otherwise unrepresented diversity (Vane-Wright \& al., 1991). The principle of complementarity may therefore be used to define a minimum set of cells that ensures that each taxon is represented in at least one cell. Calculating a minimum set is an NP-complete problem but the 'near-minimum set' algorithm implemented in WORLDMAP provides a heuristic solution to this problem (Williams \& al., 1996). This algorithm was used to calculate near-minimum sets for both total endemic taxon diversity and threatened taxon diversity to further investigate the relationship between these biodiversity measures.

\section{Results}

\section{Endemic richness (ER)}

The total number of cells included in the analysis was 136 and as can be seen from Fig. 2a, there was considerable variation in the land area within cells. Range sizes of taxa included in the analysis ranged from 1-87 cells ( mean $=8.59$; median $=4$ ) and the complete data matrix included a total of 5232 occurrence data. Endemic richness of cells (Fig. 2a) ranged from 1 to 139 taxa per cell $(0.05-22.82 \%$ of total taxon diversity).

For the most part, Fuerteventura and Lanzarote exhibit very low levels of ER (Fig. 2a). This is probably a reflection of the low habitat diversity of these two islands (Rodríguez Delgado \& al., 2000; ReyesBetancort \& al., 2001) coupled with the impact of human activity on the diversity of the native flora. In Lanzarote, 10 of the 17 cells contain less than 10 taxa (i.e. ER $\leqslant 1.64 \%$ ); whilst in Fuerteventura the proportion is even higher with 24 of the 30 cells exhibiting ER scores of less than, or equal to, $1.64 \%$. This is in marked contrast to the richness of other islands wherein only three cells in Gran Canaria have similarly low ER scores. The most endemic rich area in Fuerteventura is the Jandía massif in the south of the island (16-44 taxa; ER = 2.63-7.22\%) whilst the richest area in Lanzarote is the Famara massif in the north (16-46 taxa; $\mathrm{ER}=2.63-7.55 \%)$. These two massifs are relatively old formations with significant altitudinal variation and high cliffs (Coello \& al., 1992). Within Fuerteventura, Montaña Cardones to the northeast of Jandía is the next richest area (18 species; ER = $2.96 \%$ ). At $691 \mathrm{~m}$, this mountain is not as high as other, less taxon rich mountains in Fuerteventura, but its steep and difficult terrain may have limited the extent of human impact that has elsewhere in the island impacted substantially on the native vegetation (Ro- 

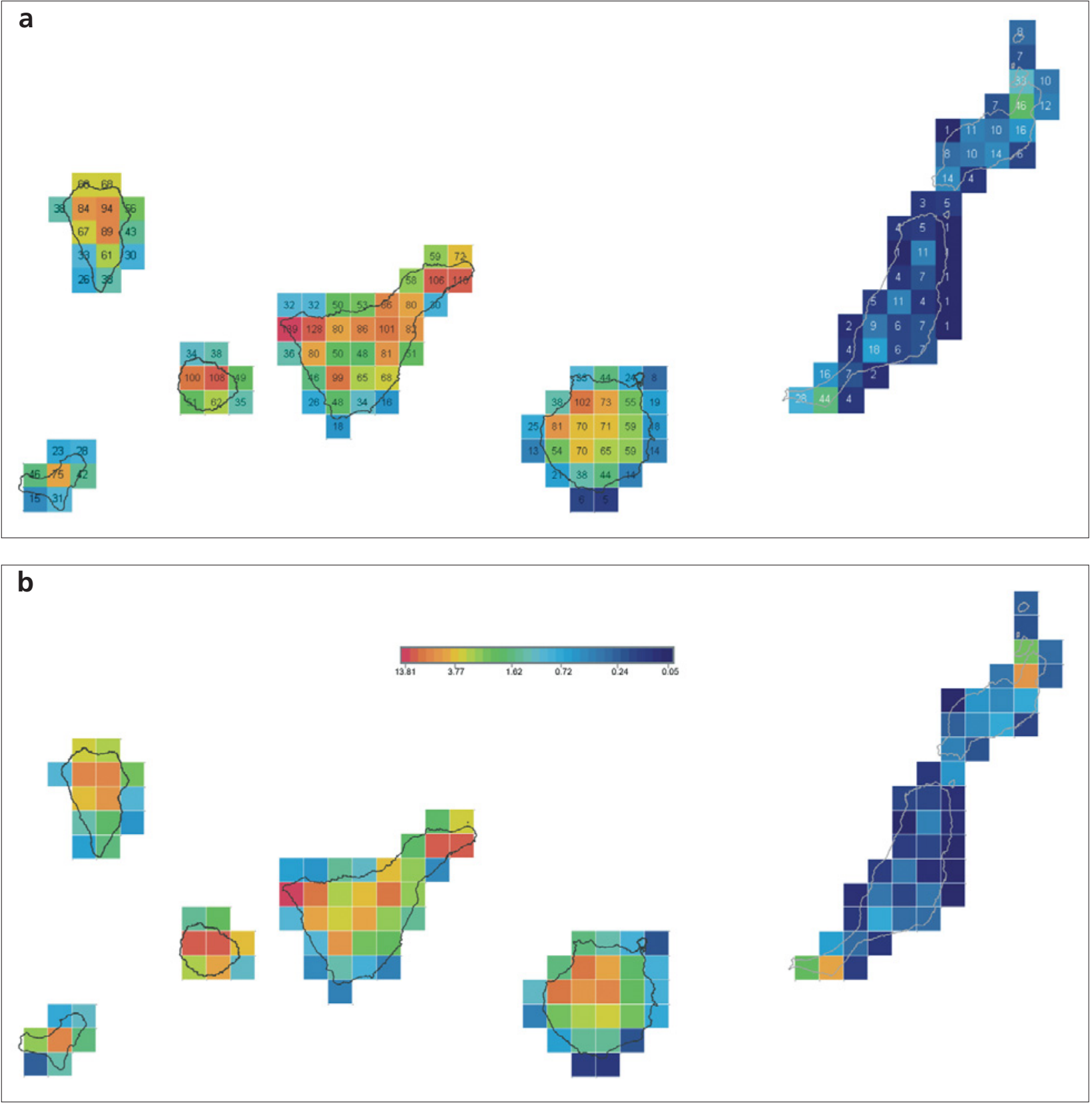

Fig. 2. Patterns of diversity in the Canary Island flora: a. Endemic species richness (ER). b. Range size rarity (RSR). c. Phylogenetic diversity (PD). $\mathbf{d}$. Threatened taxon diversity (TD). An equal frequency scale with the maximum shown as a separate class is used. Numbers in cells in Fig. 2a and 2d correspond to the number of taxa present in each case. For Figs. 2b and 2c a scale bar is provided.

dríguez Delgado, 2005). In Lanzarote, the Ajaches massif in the south $(608 \mathrm{~m})$, the second highest point of the island after Peñas del Chache $(670 \mathrm{~m})$, shows somewhat higher endemic richness than other nearby cells (14 taxa; ER $=2.30 \%$ ). The area in the southeast of the island that includes Montaña Blanca is also richer than most other cells in Lanzarote (14 taxa; ER $=2.30 \%)$. Whilst other nearby areas, notably Montaña Guardilama $(603 \mathrm{~m})$ show greater altitude, the Montaña Blanca cell is further from the Timanfaya volcano and is therefore likely to have been less affected by recent volcanic activity (1730-36).

In Gran Canaria, the precipitous and humid Tamadaba massif (del-Arco \& al., 2002) is identified as the area of highest endemic richness (Fig. 2a, 102 taxa; $E R=16.75 \%)$. Adjacent areas to the southwest and east (81 taxa, ER $=13.30 \%$ and 73 taxa, ER = $11.99 \%$ respectively) and the high mountains in the centre of the island (65-71 taxa; $\mathrm{ER}=10.67-11.66 \%$ ) are also rich in taxa (Fig. 2a). There is a general de- 

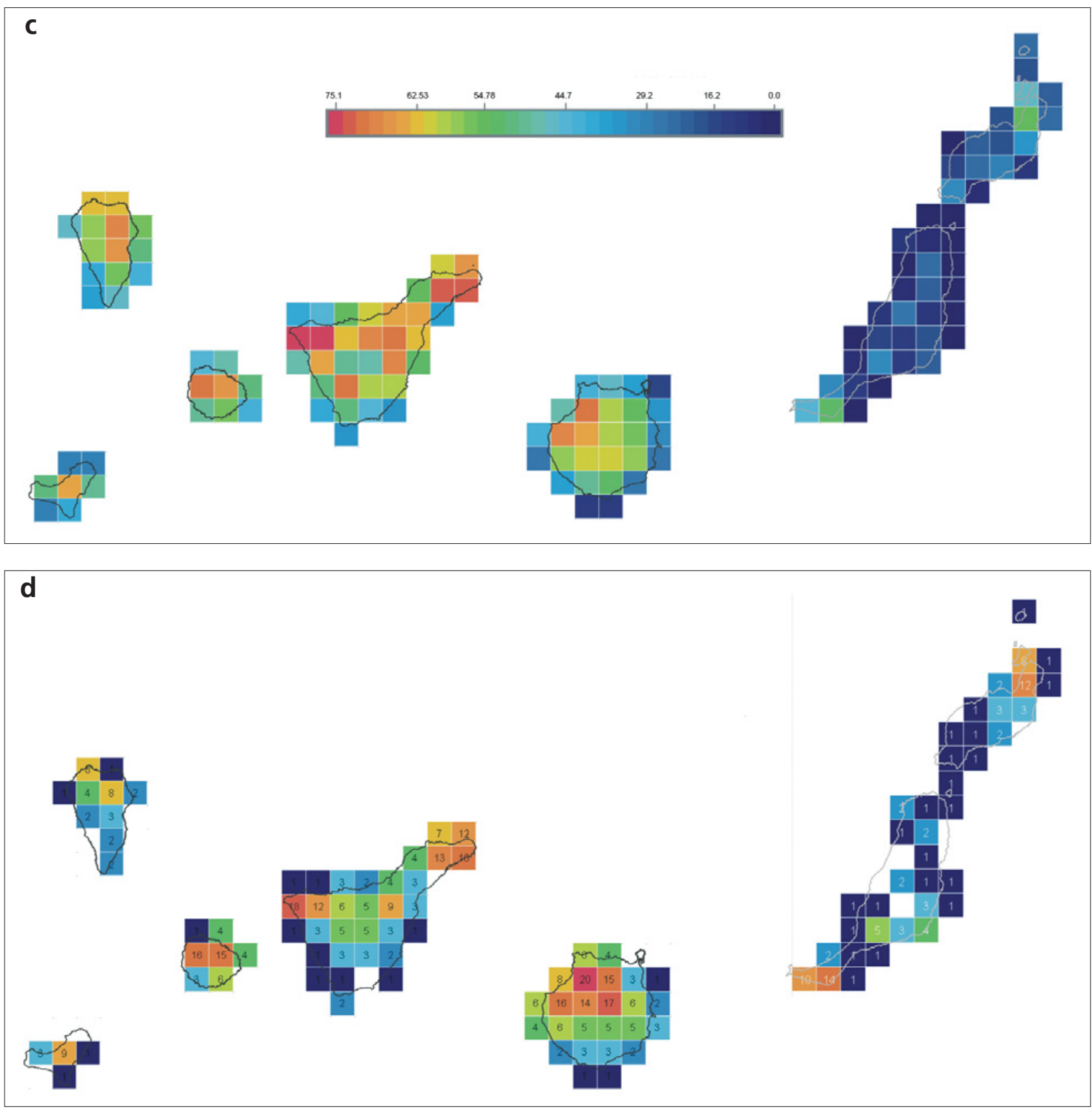

Fig. 2. (Continuation).

crease in species richness towards the south and east of the island and this correlates with a decrease in altitude and humidity (del-Arco \& al., 2002).

The grid cell with the highest endemic richness overall in the analysis corresponds to the west of the Teno massif on Tenerife (Fig. 2a; 139 taxa; endemic richness $=22.82 \%$ ) whilst the adjacent cell that includes the eastern end of the massif is the second richest overall with 128 taxa recorded (endemic richness $=21.02 \%)$. Teno is one of the oldest regions of Tener- ife (6.2-5.6 Myr old) and was one of three palaeo-islands that existed independently until volcanic activity approximately $3 \mathrm{Myr}$ ago led to formation of the single island of Tenerife (Carracedo \& Day, 2002). Within Teno, variation in species richness observed between these two cells may be explained by differences in altitudinal range and humidity, both of which are greatest in the west of the massif. Cells corresponding to the other two Tenerife palaeo-islands (Anaga and Adeje) also exhibit high species richness. 
Thus, grid cells corresponding to the 4.9-3.9 Myr old Anaga massif (Carracedo \& Day, 2002) in the northeast of the island contain $110(\mathrm{ER}=18.06 \%)$ and 106 $(\mathrm{ER}=17.41 \%)$ taxa respectively whilst the cell that includes the 11.9-8.9 Myr old Adeje massif (Carracedo \& Day, 2002) contains 99 taxa $(E R=16.26 \%$ richness). Other cells within Tenerife with high endemic richness scores are those that include the Ladera de Güimar (101 taxa; ER = 16.58\%), the Barranco de Herques/Barranco de Tamadaya (81 taxa; ER = $13.30 \%$ ) and Guía de Isora (80 taxa; ER $=13.14 \%$ ). The Valle de Güimar, created by a substantial landslide, has a high altitudinal range and, uniquely within the south of Tenerife, is influenced by the North East trade winds, creating a humid climate (del-Arco \& al., 2006). Both factors are likely to contribute to the high diversity and concentration of endemics in this area. The deep ravines of Barranco de Herques and Barranco de Tamadaya in the south of the island provide humid conditions in an otherwise arid part of the island, resulting in relatively high species richness in this area. The Guía de Isora region, south of the Teno massif includes areas of relatively recent origin with large lava flows still evident. However, the region exhibits a relatively high altitudinal range and habitat diversity that may account for the diversity of this cell.

The general influence of the trade winds on species diversity in Tenerife is evident from the higher levels of endemic richness observed when the north of the island (excluding coastal cells of limited land surface area, all cells have at least 80 taxa and ER scores $\geqslant 13.14 \%$ ) is compared with the south (all cells have less than 68 taxa per cell and ER scores $\leqslant 11.17 \%$ if cells containing the Adeje massif, Ladera de Güimar and Barranco de Herques/Barranco de Tamadaya are excluded). Las Cañadas in the centre of the island is markedly less diverse than surrounding cells with only $50(\mathrm{ER}=8.21 \%)$ and 48 taxa $(E R=7.88 \%)$ respectively recorded from the two cells that correspond to this region of recent volcanic activity (0.17 Myr old; Carracedo \& Day, 2002).

In La Gomera, the highest taxon diversity is observed in the central-north area of the island, an area that includes the highest peaks and is under strong influence of the trade winds (Fig. 2a). The two cells comprising this region have 100 and 108 taxa respectively ( $\mathrm{ER}=16.42 \%$ and $17.73 \%$ ). Diversity in the coastal areas of the north and east is lower although this may be an artifact of the limited land surface of these cells. The drier south of the island is also less diverse although the south-central region that extends into higher altitude areas is more diverse than the southwestern cell (62 taxa; ER $=10.18 \%$ ).

The highest taxon diversity in La Palma is found on the north east of the island (Fig. 2a, 94 taxa; ER = $15.44 \%$ ). This represents the eastern side of the island's
Caldera, an area of high humidity, strongly influenced by the trade winds (del-Arco \& al., 1999) and with a large altitude range. Cells corresponding to the west of the Caldera ( 84 taxa; ER $=13.79 \%$ ) and the Cumbre Nueva ( 89 taxa; $E R=14.61 \%$ ) are also taxon rich as is the cell representing the Barranco de Angustias region that constitutes the lower, western part of the caldera (67 taxa; $E R=11.00 \%$ ). The Cumbre Vieja, the major mountain range in the south of the island and a region of recent volcanic activity, is somewhat less diverse with 61 taxa $(E R=10.02 \%)$ despite the high altitude range and habitat diversity of the area. Coastal areas in La Palma are generally lower in diversity although the humid steep cliffs and deep ravines of the northern coast are taxon rich, particularly when the limited land area of these cells is considered ( 68 taxa; $E R=11.17 \%$ ).

In El Hierro, the highest diversity is found in the central cell (Fig. 2a, 75 taxa; endemic richness $=12.32 \%$ ). The high diversity of this cell may be explained by the occurrence of the highest point of the island (Malpaso, $1503 \mathrm{~m})$, together with old, exposed rocks (1.1-0.9 Myr; Guillou \& al., 1996) and the steep, $1 \mathrm{~km}$ high Riscos de Tibataje of El Golfo all within it. Several El Hierro endemics occur only within this cell (e.g. Adenocarpus ombriosus Ceball. \& Ortuño, Bencomia sphaerocarpa Svent., Crambe feuilleei A.Santos ex Prina \& Mart.-Laborde). The adjacent cell that includes the western end of El Golfo (Riscos de Bascos) is less rich in taxa ( 46 taxa $E R=7.55 \%$ ). This may be explained by the limited land area of this cell coupled with the lower humidity and lower altitude with Juniperus woodlands rather than laurel forest found at its highest point. The south and east of El Hierro are the youngest areas of the island. They are drier and more heavily influenced by recent volcanic activity (<134 ka; Guillou \& al., 1996) and this is reflected in relatively low taxon diversity within these cells (15-42 taxa; $E R=2.46-6.90 \%)$.

\section{Range size rarity (RSR)}

RSR scores for cells ranged from $0.01-13.81 \%$ (Fig $2 \mathrm{~b})$. As with ER, the highest scoring cell overall is that representing the Western end of the Teno massif in Tenerife $(13.81 \%)$ and it is apparent from comparison of RSR scores (Fig. 2b) and ER scores (Fig. 2a) that the two measures are related. The highest scoring cell in each island is the same for each measure and in general, cells exhibiting high ER scores are also typically rich in endemics of limited distribution. The Spearman Rank correlation coefficient [rho $=0.957$, $\mathrm{t}(133 \mathrm{df})=38.014 ; \mathrm{p}<0.0005$ (single tail) $\mathrm{p}<0.001$ (two tail)] further suggests that the two measures are highly correlated and this is supported by examination of the residuals from this correlation (Fig. 3a) that reveal little deviation from the correlation. 


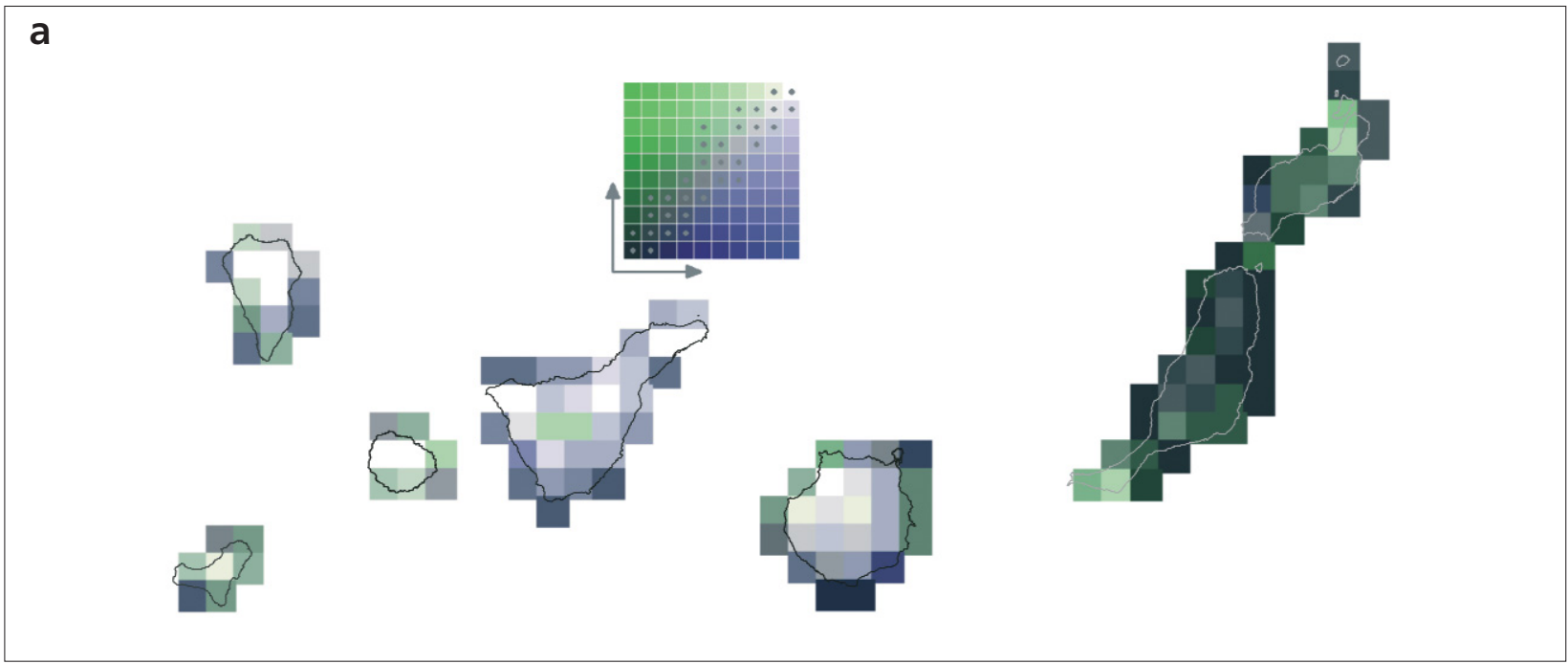

\section{b}
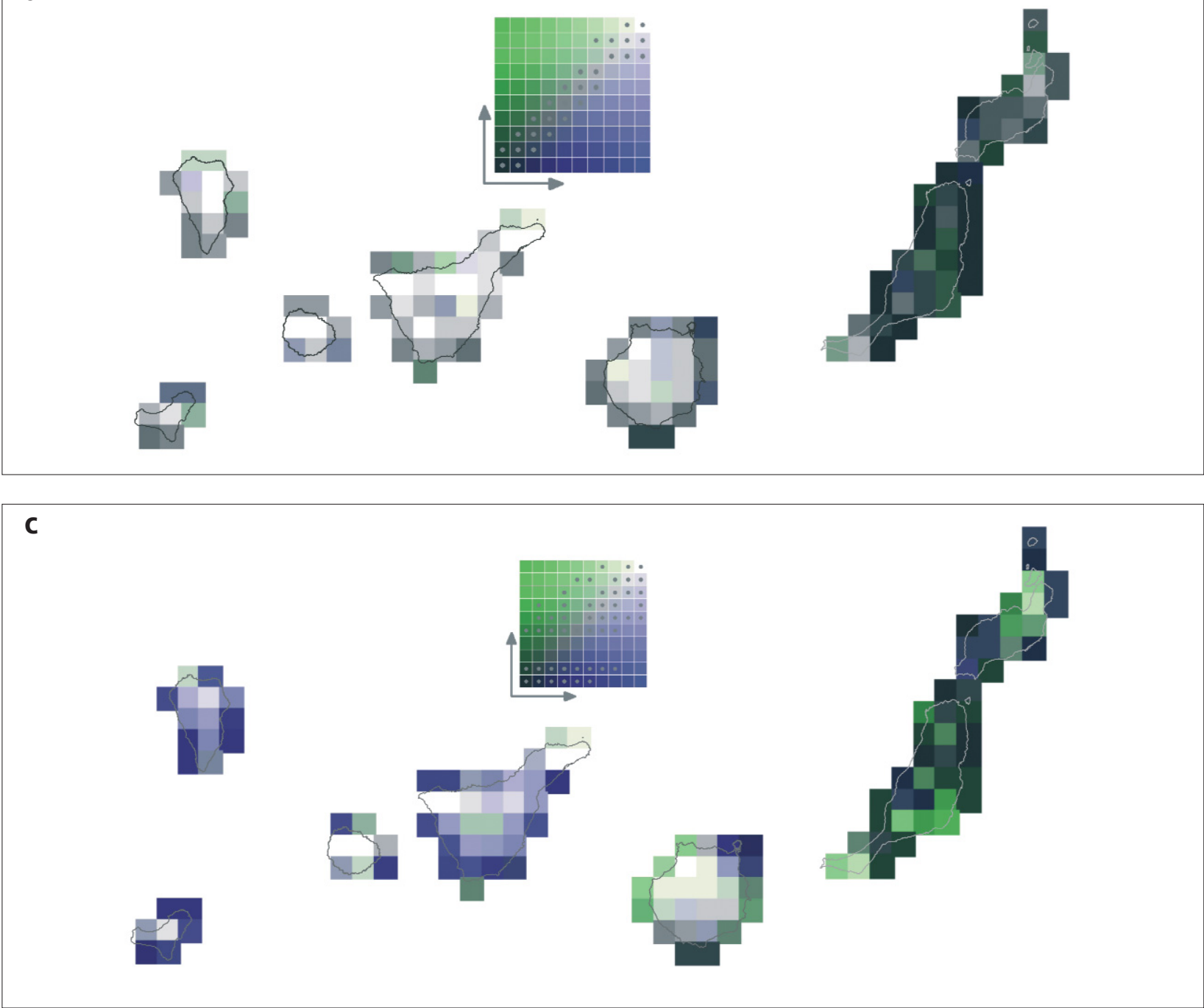

Fig. 3. Correlation of (a) range size rarity (RSR), (b) phylogenetic diversity (PD) and (c) threatened taxon diversity (TD) with endemic taxon richness (ER) in each case. Graphs show the extent of deviation from the correlation; maps show the geographical pattern of deviations from correlations. In each case, squares coloured white-grey fit the prediction; whilst those coloured green have higher ER than predicted from the correlation and cells coloured blue-purple have lower ER scores than predicted from the correlation. 
Cells that do deviate markedly from the generally close correlation between these two measures include those representing the Cañadas region of Tenerife that demonstrate higher range size rarity scores than their endemic richness scores would predict. The number of taxa that occur in this area of relatively recent volcanic activity is limited (Fig. 2a), but a high proportion of species in the area are local endemics that are either strictly confined to Las Cañadas or are limited to Las Cañadas and adjacent areas. In Fuerteventura and Lanzarote, the Jandía and Famara massifs also demonstrate markedly higher range size rarity scores than would be predicted from their endemic taxon richness scores reflecting the generally low levels of diversity but high incidence of species in these cells that are endemic to these areas. Other cells deviating markedly from the correlation include the cell representing the east of $\mathrm{La}$ Gomera, that representing the extreme northwest of Gran Canaria (the Montaña Amagro/Montaña de Gáldar region) and the cell containing the Isla de Lobos in Fuerteventura. Each of these three cells also exhibit higher range size rarity scores than would be predicted from their endemic richness scores. Two cells exhibit markedly lower range size rarity scores than would be predicted from their endemic richness scores: the cell in the southeast of Gran Canaria that contains the lower parts of the Barranco de Tirajana and the Barranco Hondo, and the cell that is located to the south of the Isora region and to the west of Las Cañadas in Tenerife. This probably reflects the limited topographic variation of these areas, both of which exhibit little topographic heterogeneity.

\section{Phylogenetic diversity (PD)}

PD ranged from $0-75.91 \%$ (Fig 2c), with a PD of $0 \%$ recorded for cells that contain a single Canary Island endemic taxon and hence no phylogenetic diversity. In Tenerife, the two cells representing the Teno massif showed the highest PD overall (75.91\%). High $\mathrm{PD}$ values also found in the cells representing the two other Tenerife palaeo-islands of Anaga (74.35\%) and Adeje $(70.98 \%)$. The highest scoring cell in $\mathrm{La}$ Gomera is that which includes the West of Garajonay together with Valle Gran Rey (69.43\%). It is notable that whilst this cell has a higher PD score than the adjacent cell that includes the centre and east of Garajonay (PD $=66.06 \%)$, the scores for ER and RSR are both higher in the latter. Within the remaining islands, the highest scoring cell for PD is also the highest scoring cell for both RSR and ER and the Spearman Rank correlation coefficient for the correlation between ER and PD (rho $=0.992, \mathrm{t}(134 \mathrm{df})=91.109 ; \mathrm{p}<0.0005$ (single tail) $\mathrm{p}<0.001$ (two tail)) suggests a strong cor- relation between these two measures. Examination of the fit of cells to the correlation (Fig 3b), demonstrates that this is indeed the case, with few cells deviating strongly.

\section{Threatened taxon diversity (TD)}

In contrast to the other three measures employed in this paper, each of which identified the west of the Teno massif as the highest scoring area (Figs. 2a-c), the cell containing the Tamadaba massif within Gran Canaria was found to contain the highest score when TD is measured (20 taxa, Fig. 2d). The west of the Teno massif (18 taxa) was ranked second with the cell corresponding to the high mountains of Gran Canaria (17 taxa) ranking third overall. Equal fourth in TD are the cells corresponding to (i) the West of Garajonay and the Valle de Gran Rey in Gomera, (ii) the eastern end of the Anaga massif and (iii) the Inagua region of Gran Canaria that each contained 16 threatened taxa. In contrast to the other analyses (Figs. 2a-c), the Jandía massif of Fuerteventura (14 taxa) and the Famara massif of Lanzarote (12 taxa) were ranked higher than any cell in the two westernmost islands of La Palma and El Hierro wherein the cells with the highest TD scores contained eight and nine endangered taxa respectively (Fig. 2d).

The Spearman Rank Coefficient of the correlation between TD and ER suggests that the two measures are significantly correlated $[\mathrm{rho}=0.678, \mathrm{t}(134 \mathrm{df})=$ 10.689 , p, 0.005 (single tail) $\mathrm{P}<0.001$ (two tail)]. However, it is apparent from examination of the fit of cells to the correlation that there is significant deviation from the correlation and that the deviation is geographically structured (Fig. 3c). Thus, in Lanzarote and Fuerteventura, cells that deviate from the predicted relationship have higher TD scores than would be predicted from their ER scores (coloured green) whereas in Tenerife, El Hierro, La Palma and La Gomera, the converse is generally true with cells deviating from the correlation showing lower TD scores than predicted (coloured blue). In Gran Canaria, the situation is more complex: the relatively taxon-poor northeast of the island shows lower TD than predicted whereas elsewhere within Gran Canaria, the opposite is true for cells differing markedly from the correlation (Fig. 3c), although cells deviating from the correlation are, for the most part, cells with low ER scores overall (Fig. 2a).

\section{Near minimum set analyses}

The near-minimum set analysis for ER identified 53 cells that collectively ensured that all analysed taxa were represented at least once (Fig. 4a). Of these, 6 were fully flexible, with a range of possible cells equal- 

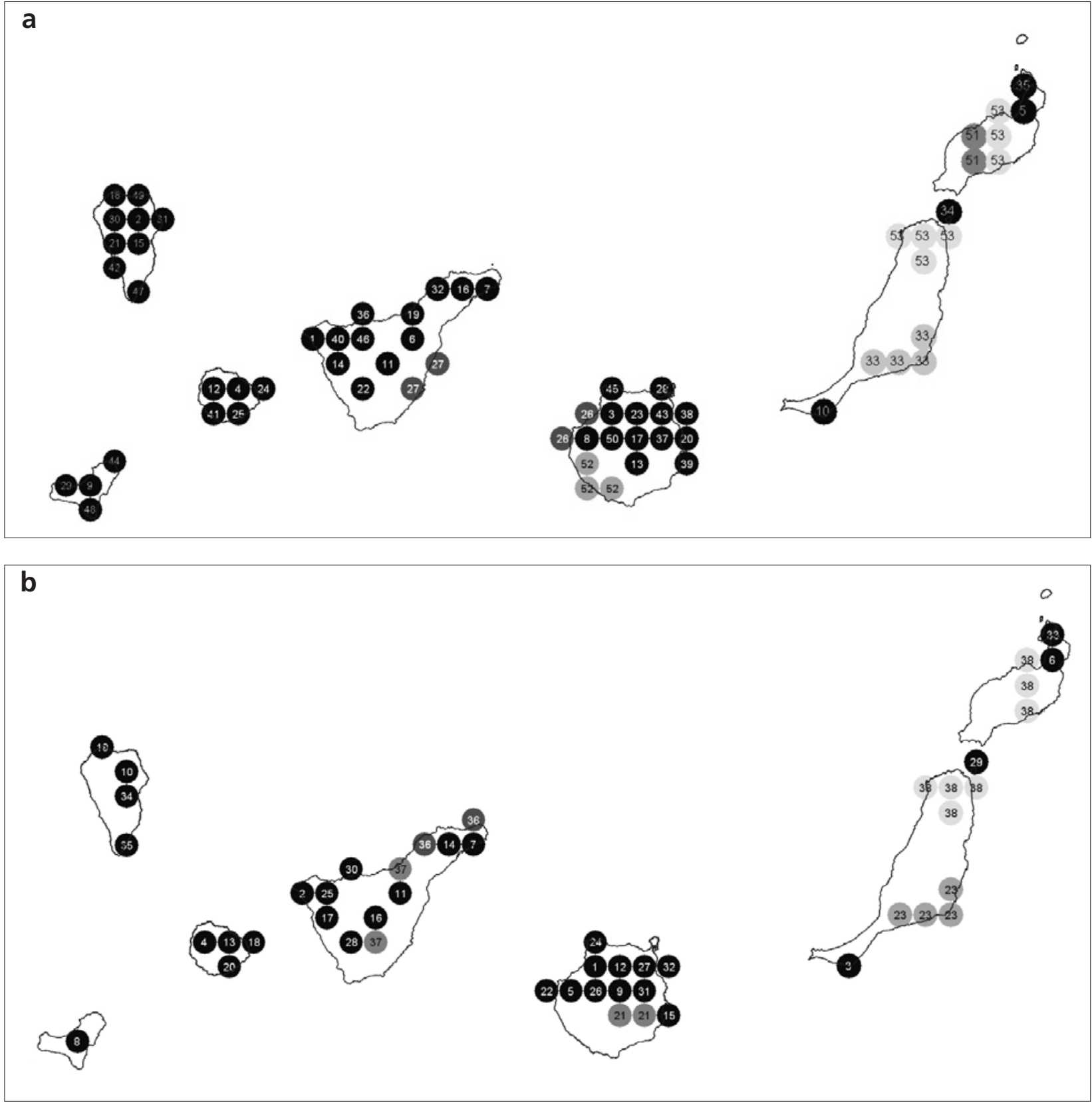

Fig. 4. Near-minimum sets for (a) all taxa in the analysis and (b) spermatophyte taxa listed in Bañares \& al. (2004) that are endemic to the Canary Islands. Numbers in cells indicate complementarity value. Thus, the cell ranked first in each case accounts for the greatest number of species, whilst the cell ranked second adds the greatest amount of diversity not represented in the first cell and the cell ranked third adds the greatest amount of diversity not represented in the first or second, etc. Black circles = inflexible; grey circles $=$ flexible cells, i.e. where a number of cells could be selected.

ly suitable for designation as protected whilst the remaining 47 cells demonstrated no flexibility.

The near-minimum set analysis for TD required fewer cells, 38 in all (Fig. 4b). Of these, 5 were fully flexible and 33 demonstrated no flexibility at all. From comparison of the near-minimum sets for these two data sets, it is apparent that the set specified when the analysis is confined to threatened taxa differs markedly from that specified when all taxa are considered. In Gran Canaria, Lanzarote and Fuerteventura, 16 of the 21 areas $(76 \%)$ that were identified in the ER analysis (Fig. 4a) are also recovered in the TD analysis (Fig. 4b), whereas in the remaining islands, only 20 of the 31 cells in the ER analysis (Fig. 4a, 64\%) are also recovered in the TD analysis. The discrepancy is most pronounced in the western islands of $\mathrm{La}$ 
Palma and El Hierro, wherein less than half of the cells included in the near minimum set based on ER are recovered in the near-minimum set based on threatened TD.

\section{Discussion}

\section{Patterns of diversity}

The goals of this paper were threefold: to describe patterns of ER across the Canary Islands archipelago, to investigate the extent to which other measures of diversity exhibit similar patterns to ER and to consider the implications of these results for our understanding of the mechanisms promoting the evolution of endemic diversity and for the conservation of the region's flora.

The results of the analysis of patterns of ER (Fig. 2a) highlight the highly heterogeneous distribution of endemic diversity across the archipelago. Analyses of RSR (Fig. 2b) and PD (Fig. 2c) result in patterns that are largely congruent with ER (Figs. 3a,b), although there are some differences, notably in the higher RSR scores exhibited by Las Cañadas of Tenerife, Jandía in Fuerteventura and Famara in Lanzarote than would be predicted from their ER scores (Fig. 3a). The geographical pattern of TD (Fig. 2d) differs substantially from that of ER as is evident when a correlation between these two scores is attempted (Fig. 3c). The decoupling of TD and ER and, to a lesser extent the differences observed between RSR scores and ER are significant for conservation planning as the use of any one measure alone to inform conservation actions would risk compromising the conservation of other aspect of the region's diversity.

The fact that hotspots of PD (Fig. 2c), ER (Fig. 2a) and, indeed, RSR (Fig. 2b) within the Canary Islands are largely coincident raises two questions regarding the evolution of the Macaronesian endemic flora: firstly, why is endemic Canary Island diversity concentrated within distinct hotspots and secondly, how has the diversity within these areas accumulated in space and time?

\section{The evolution of Canary Islands diversity}

Building on a long history of research on the evolution of Canary Islands plant diversity (e.g. Bramwell, 1972; Humphries, 1979), the Emerson \& Kolm (2005) 'diversity begets diversity model' and the Whittaker \& al. (2007) 'island immaturity-speciation pulse model' were both recently developed to explain differences between levels of species richness and endemicity between islands. However, both are also consistent with the intra-island patterns of variation in ER (Fig. 2a) and RSR (Fig. 2b) that we describe in this paper. A close correlation between the proportion of single island endemics and total species richness led Emerson \& Kolm (2005) to suggest that high species diversity drives higher speciation rates. Whilst sampling in the present study was confined to the endemic flora (i.e. excluding the ca. 600 taxa considered native but nonendemic), the close correlation at the intra-island level observed between ER and RSR (Fig. 3a) suggests that the relationship observed at the between-island level by Emerson \& Kolm (2005) that underpins their model may also scale to the intra-island level. Whittaker \& al. (2007) predicted that both species richness and speciation rate will reach a maximum when an island reaches maximum topographic complexity and it is notable that the cell within each island that contains the highest ER (Fig. 2a), RSR (Fig. 2b) and PD score (Fig. 2c), in all cases, also contains relatively old massifs with significant altitudinal variation. It is also apparent however, that other factors may also influence taxon richness and endemicity within the archipelago. For example, in Tenerife, cells that include the Ladera de Güimar and the Barranco de Herques/Barranco de Tamadaya have higher ER and RSR scores that many other cells in the south of Tenerife. This may be related to the higher humidity of these areas. Further analyses of the patterns of intra-island ER and RSR that we describe in this paper, in conjunction with data on abiotic factors at the intra-island level may provide further insights into the processes driving diversification in insular systems.

Molecular phylogenetic analyses of the Canary Islands flora have demonstrated that evolutionary radiations of lineages within the archipelago are responsible for much of the endemic species diversity present. Humphries (1979) suggested that allopatric speciation was an important mechanism generating endemic diversity in the Canary Islands and this hypothesis has been supported by molecular phylogenetic analyses which suggest that, whilst ecological shifts have been an important mechanism for generating endemic diversity, geographical isolation through inter-island colonisation between similar ecological zones has also played a major role (Francisco-Ortega \& al., 2001; Allan \& al., 2004, Trusty \& al., 2005). The strong correlation between PD and ER demonstrated in this paper further suggests that the diversity contained within the region's diversity hotspots are not the result of the highly localised adaptive radiation of lineages but are rather the result of the accumulation of different lineages within hotspot areas. This is in contrast with the situation in the Cape flora of South Africa, wherein Forest \& al. (2007) proposed that the decoupling of PD and taxon richness was due to the localised radiation of closely related genera within the Western Cape region. 
The two cells that show the greatest deviation from the correlation between PD and ER in the Canary Islands are (i) the cell representing the northwest of the Caldera of La Palma, which has a markedly lower PD than would be predicted from the ER score of this cell, and (ii) the cell representing the northern, lower slopes of the Orotava valley, which demonstrates a higher PD than would be predicted from the ER score. Within the La Palma cell, 84 Canary Island endemic taxa are present. These belong to 59 generic/intrageneric groupings (on average, 1.42 taxa per group) with 18 groups represented by two or more taxa within this cell. Whilst this cell exhibits high ER relative to its PD score, only one taxon, Lactucosonchus beltraniae (U. Reifenberger \& A. Reifenberger) Bramwell is strictly endemic to this cell. Furthermore, whilst molecular data suggest that Bystropogon origanifolius L'Hér. from La Palma and El Hierro and the northern La Palma endemic B. wildpretii, which both occur in this cell, form a well supported clade (Trusty $\&$ al., 2005), molecular analyses of other groups suggest that congeners present in this cell are typically resolved within different subclades of their respective Macaronesian groups (e.g. Aeonium, Mort \& al., 2002; Cheirolophus, Susanna \& al., 1999; Bencomia, Helfgott \& al., 2000; Pericallis, Panero \& al., 1999). The lower PD than predicted from the ER in this cell may therefore be an artefact of the generic-level phylogeny used to estimate PD. With a more resolved phylogeny we would predict that this cell would conform more closely to the correlation between PD and endemic species richness.

Biogeographic analyses within the Canary Island archipelago to-date have typically focussed on individual groups and have used the islands as the basic biogeographic unit to examine spatial patterns (e.g. Panero \& al., 1999; Francisco-Ortega \& al., 2001; Barber \& al., 2002). The only comparative analysis of the relationships of taxa endemic to hotspot areas within islands was performed by Trusty \& al. (2005), who examined the relationships of taxa endemic to the three palaeo-islands of Tenerife, each of which may be considered a biodiversity hotspot under one or more of the measures employed here (Fig. 2a-c). More than $60 \%$ of taxa endemic to the Tenerife palaeo-islands have been investigated using molecular phylogenetic approaches and Trusty \& al. (2005) found that in most cases, taxa endemic to these areas are resolved as part of the crown groups of their respective phylogenies suggesting a recent origin. However, some early branching or isolated lineages were also found to be endemic to the Tenerife palaeo-islands (e.g Hypochaeris, Navaea, Sonchus, Vieria) suggesting that the endemic flora of these biodiversity hotspot areas is a mixture of both recent and old en- demic lineages. The concentration of endemic diversity into distinct intra-island centres of diversity with, at least in the case of Tenerife, several present on a single island, suggests that the use of islands as the basic unit for biogeographic analyses may be too simplistic. Indeed, it may even obfuscate biogeographic patterns, particularly when a broader sample of groups is investigated. Within-island areas of the sort used by Trusty $\&$ al. (2005) for their analysis may be more appropriate units for biogeographic analysis of the Canary Island flora and identifying areas of endemism within the archipelago to analyse in conjunction with explicit phylogenetic hypotheses for Canary Island endemic lineages and may facilitate a better understanding of the evolution of the endemic flora of the Canary Islands archipelago in space and time.

\section{The conservation of Canary Islands diversity}

Protected areas are one of the most effective tools for safeguarding biodiversity (Langhammer \& al., 2007). The current protected area network of the $\mathrm{Ca}$ nary Islands is extensive in coverage and collectively accounts for approximately $40 \%$ of the archipelago's total area (http://www.gobcan.es/cmayot/espaciosnaturales/categorias/ase.html), considerably more than the $10 \%$ minimum that the IUCN recommends should be set aside for conservation in each major biome (see Langhammer \& al., 2007). However, the need for an extensive network of protected areas in the $\mathrm{Ca}$ nary Islands is supported by the near-minimum set analyses for ER and TD, which required 53 cells (Fig. $4 \mathrm{a} ; 38 \%$ of all cells) and 38 cells (Fig. $4 \mathrm{~b} ; 27 \%$ of all cells) respectively, particularly as minimum sets provide only a lower bound for the size of an effective network and are unlikely to be sufficient for ensuring the long-term persistence of the species involved (Rodrigues \& Gaston, 2001). Furthermore, the present analysis considers only endemic spermatophyte taxa; expanding the analysis to include other groups is likely to expand the size of the network required for the effective conservation of the region's biota still further.

From the correlation between ER and TD (Fig. 3c) it is apparent that in Lanzarote, Fuerteventura and much of Gran Canaria, cells deviating markedly from the correlation tend to have a higher threatened taxon diversity than would be predicted from the endemic taxon richness of these cells. In contrast, cells in the western islands that deviate markedly from the correlation tend to have a lower threatened taxon diversity than would be predicted from their endemic taxon richness. This is consistent with the fact that the vegetation of the three easternmost islands within the archipelago have suffered most from human impact 
(Suárez, 1994; Reyes-Betancort \& al., 1998; Rodríguez Delgado, 2005). The results of the near-minimum set analyses for ER (Fig. 4a), and TD (Fig. 4b), further highlight the differences between the patterns of ER and TD across the archipelago, as the proportion of cells specified in the near-minimum set analysis for endemic taxon diversity that are also specified in the analysis for threatened taxon diversity is higher in the eastern than in the western islands $(76 \%$ and $64 \%$ respectively).

Table 1 shows how the ten highest-ranked cells in the near-minimum set for ER (Fig. 4a) are ranked in the TD analysis (Fig. 4b) and how the corresponding IPA is ranked in the analysis of del-Valle \& al. (2004). From Table 1, it is clear that some areas have a broadly comparable ranking across all thee analyses, notably the Teno massif that is ranked first overall in the nearminimum set analysis of ER, first within all of Spain by del-Valle \& al. (2004) and second in the TD near-minimum set analysis (Table 1, Fig. 4). The ranking of the cell corresponding to the Riscos de Malpaso and Tibataje en Frontera IPA is also broadly consistent across all three analyses (Table 1). Other cells, however, differ markedly in their ranking in the three analyses. For example, Jandía is ranked third overall in the near-minimum set analysis for TD with the corresponding IPA ranked fourth in the Canaries by delValle \& al. (2004) whilst in the near-minimum set analysis, based on ER scores, this cell is ranked tenth overall. In the case of the cell including the Ladera de Güímar IPA, the difference is even more pronounced, as the IPA is ranked 21st in the Canaries by del-Valle \& al. (2004) whilst the cell within which the IPA is located is ranked eleventh in the near-minimum set analysis of TD and sixth in the analysis of ER (Table 1). The greatest discrepancy highlighted by Table 1 concerns the relative ranking of the cell containing Cañadas del Teide. This cell is ranked eleventh in the ER analysis, sixteenth in the TD analysis and 57th in the Canary Islands in the del-Valle \& al. (2004) analysis.

The discrepancies between the relative ranking of cells in the present analysis and in the analysis of delValle \&. al (2004) are in part attributable to differences in the methodological approach and in the underlying data: del-Valle \& al. (2004) weighted taxa by threat, to arrive at scores for each cell, whereas we simply consider the number of endemic/threatened species per cell; del-Valle $\&$ al. (2004) used a $1 \times 1 \mathrm{~km}$ UTM grid, whereas we used a $10 \times 10 \mathrm{~km}$ grid; our analysis was confined to spermatophytes, whereas

Table 1. Comparison of the twelve highest ranked Canary Island cells in the near-minimum set of cells based on total endemic richness (ER; Fig. 3a) with the ranking of those cells in the near-minimum set of cells based on threatened taxon diversity (TD; Fig. 3b) and the corresponding Important Plant Areas for Endangered plants recognised by del Valle \& al. (2004).

\begin{tabular}{|c|c|c|c|c|}
\hline $\begin{array}{l}\text { Rank of cell in the } \\
\text { near-minimum set analysis } \\
\text { for total endemic taxon } \\
\text { diversity }\end{array}$ & $\begin{array}{l}\text { Rank of corresponding cell } \\
\text { in the threatened taxon } \\
\text { near-minimum set } \\
\text { analysis }\end{array}$ & $\begin{array}{l}\text { Rank within the Canary } \\
\text { Islands in the del Valle \& al. } \\
\text { (2004) IPA analysis } \\
\text { (in parentheses, overall } \\
\text { rank within Spain) }\end{array}$ & $\begin{array}{c}\text { Corresponding Important } \\
\text { Plant Area of del Valle \& } \\
\text { al. (2004) }\end{array}$ & Island \\
\hline 1 & 2 & $1(1)$ & $\begin{array}{c}\text { Punta de Teno, Masca } \\
\text { and Monte de Agua }\end{array}$ & Tenerife \\
\hline 2 & 10 & $11(12)$ & $\begin{array}{l}\text { Crestas de Taburiente } \\
\text { and northern ravines }\end{array}$ & La Palma \\
\hline 3 & 1 & $8(9)$ & Tamadaba & Gran Canaria \\
\hline 4 & 13 & $3(3)$ & Garajonay (E) & La Gomera \\
\hline 5 & 6 & $12(13)$ & Riscos de Famara & Lanzarote \\
\hline 6 & 11 & $21(26)$ & Ladera de Güimar & Tenerife \\
\hline 7 & 7 & $2(2)$ & Punta de Anaga & Tenerife \\
\hline 8 & 5 & $5(6)$ & $\begin{array}{c}\text { Inagua, Barranco de la } \\
\text { Aldea, Bentayga } \\
\text { and Pino Gordo }\end{array}$ & Gran Canaria \\
\hline 9 & 8 & 10(11) & $\begin{array}{c}\text { Riscos de Malpaso and } \\
\text { Tibataje in Frontera }\end{array}$ & El Hierro \\
\hline 10 & 3 & $4(5)$ & Península de Jandía & Fuerteventura \\
\hline 11 & 16 & $57(33)$ & Cañadas del Teide & Tenerife \\
\hline 12 & 4 & $3(3)^{2}$ & Garajonay $(\mathrm{W})^{2}$ & La Gomera \\
\hline
\end{tabular}

'Some IPAs span two or more cells and some cells contain more than one IPA. The highest scoring IPA is therefore given for each cell.

2 This cell also includes the IPA Las Hayas, Arure and Epina which is ranked ninth in the IPA analysis. 
del-Valle \& al. (2004) considered all trachaeophytes; whilst del-Valle \& al. (2004) ranked cells by their weighted scores, cells were ranked by the complementarity criterion in our analysis. Furthermore the distributions of several threatened taxa have been corrected in our dataset in light of new data since the publication of Bañares \& al. (2004). However, the conflict between the results from del-Valle \& al. (2004) and particularly between the near minimum set analyses of ER and of TD presented here is consistent with the results of other studies that have shown that different measures of diversity can be strongly decoupled (e.g. Orme \& al., 2005) and should be considered in conservation planning.

A notable point of agreement between all three analyses presented in this paper and the analysis of delValle \& al. (2004) is the importance of the Teno massif for Canarian endemic plant diversity. The cell corresponding to the western end of the Teno massif exhibits the highest level of ER overall (Fig. 2a), the highest RSR score (Fig. 2b) the highest PD score (Fig. 2c) and the second highest TD score (Fig. 2d) overall. Furthermore, in the IPA analysis of del-Valle \& al. (2004), Teno is ranked first in importance in the entire network of Spanish IPAs. Sixteen taxa are strictly endemic to this cell of which three are listed in Annex 2 of the EU Habitats Directive (92/42/CEE) and eight are included in the Canary Islands red list (Gobierno de Canarias, 2000; Table 1). The Teno massif is currently protected as a Parque Rural, one of eight categories of protected area recognised in the Canary Islands. Whilst three categories of protected areas, namely Reservas Naturales Integrales, Reservas Naturales Especiales and Sitios de Interés Científico are specifically designated to conserve species, ecosystems or communities that are rare, endangered, important or unique, Parques Rurales have different goals and are managed mainly for landscape/seascape conservation and recreation and/or for the sustainable use of natural ecosystems. Within the Canary Islands, all Reservas Naturales Integrales, Reservas Naturales Especiales and Sitios de Interés Científico are additionally designated Áreas de Sensibilidad Ecológica as are all Canary Island Parques Nacionales, Parques Naturales and Monumentos Naturales. Furthermore, a total of 12 additional areas located within Parques Rurales and Paisajes Protegidos also receive this designation. Collectively Áreas de Sensibilidad Ecológica account for two thirds of the total protected area within the Canary Islands (http://www.gobcan.es/cmayot/ espaciosnaturales/categorias/ase.html). This designation acknowledges the intrinsic natural, cultural or landscape value of the area, coupled with its vulnerability and such a designation puts in place additional mechanisms to support conservation. Given the importance of the Parque Rural de Teno for the Canary Is- lands endemic and threatened flora, it is particularly notable that this area is not recognised as an Área de Sensibilidad Ecológica and a re-evaluation of the status of the Teno massif to upgrade the level of protection afforded to its unique flora would seem appropriate.

As de-Klerk \& al. (2004) noted, not all protected area networks are designed from an empirical baseline. In many instances, a further important factor in the defining the location of protected areas is history. With this in mind, analyses of the type performed here and by del-Valle \& al. (2004) can inform conservation policy by ensuring that protected area networks effectively protect biodiversity. The grid scale used in an analysis can impact on the results (Hulbert \& Jetz, 2007) and the crude granularity of $10 \times 10 \mathrm{~km}$ grid squares used in the present analysis could be improved, given the knowledge of Canarian endemic taxon distributions. Del-Valle \& al. (2004) study, whilst at a much finer granularity $(1 \times 1 \mathrm{~km}$ grid cells $)$ was restricted to taxa that are included in the Spanish red data list, accounting for only $70 \%$ of the taxa currently listed on the Canary Islands red list (Gobierno de Canarias, 2000) and 27\% of those included in the current analysis. Further work is clearly necessary to evaluate the performance of the Canary Islands protected area network and the development of fineresolution floristic-level databases such as that currently being compiled by the Proyecto Biota-Especies (http://www.gobiernodecanarias.org/cmayot/ medioambiente/biodiversidad/ceplam/bancodatos/ biota.html) will facilitate this important avenue of research. The development of such detailed floristiclevel resources will also support further research to investigate the patterns of geographical variation in the Canary Islands flora and the processes responsible for generating those patterns.

\section{Acknowledgements}

We thank Paul Williams (Dept. of Entomology, NHM) for assistance with WORLDMAP. This work was supported in part by a Royal Society International Joint Project 2004/R3 - EU grant to MAC and ASG.

\section{References}

Albach, D.C., Meudt, H.M. \& Oxelman, B. 2005. Piecing together the "new" Plantaginaceae. American Journal of Botany 92: 297-315.

Allan, G.J., Francisco-Ortega, J., Santos-Guerra, A., Boerner, E. \& Zimmer, E.A. 2004. Molecular phylogenetic evidence for the geographic origin and classification of Canary Island Lotus (Fabaceae: Loteae). Molecular Phylogenetics and Evolution 32: 123-138.

Al-Shehbaz, I.A., M.A. Beilstein \& E.A. Kellogg. 2006. Systematics and phylogeny of the Brassicaceae (Cruciferae): an overview. Plant Systematics and Evolution 259: 89-120. 
Angiosperm Phylogeny Group. 2003. An update of the Angiosperm Phylogeny Group classification for the orders and families of flowering plants: APG II . Botanical Journal of the Linnean Society 141: 399-436.

Bañares, A. Blanca, G., Güemes, J., Moreno, J.C. \& Ortiz, S. (eds.). 2004. Atlas y Libro Rojo de la flora vascular amenazada de España. Dirección General de Conservación de la Naturaleza. Madrid.

Barber, J.C., Francisco-Ortega, J., Santos-Guerra, A., Turner, K.G. \& Jansen, R.K. 2002. Origin of Macaronesian Sideritis L. (Lamioideae: Lamiaceae) inferred from nuclear and chloroplast sequence datasets. Molecular Phylogenetics and Evolution 23: 293-306.

Barquín Diez, E. \& Voggenreiter, V. 1988. Prodromus del atlas fitocorológico de las Canarias occidentales, Parte 1, Flora autóctona y especies de interés especial. Vols. 1-7.

Beltrán Tejera, E., Wildpret de la Torre, W., León Arencibia, M.C., García Gallo, A. \& Reyes Hernández J. 1999. Libro Rojo de la flora canaria contenida en la Directiva-Hábitats europea. La Laguna.

Bramwell, D. 1972. Endemism in the flora of the Canary Islands. In: Valentine, D.H. (ed.), Taxonomy phytogeography and evolution: 141-159. Academic Press. London.

Bramwell, D. 1990. Conserving biodiversity in the Canary Islands. Annals of the Missouri Botanical Garden 77: 28-37.

Bramwell, D. \& Bramwell, Z.I. 2001. Wild flowers of the Canary Islands. Madrid.

Bremer, K. 1994. Asteraceae Cladistics and Classification. Portland.

Carine, M.A., Russell, S.J., Santos-Guerra, A. \& Francisco-Ortega, J. 2004. Relationships of the Macaronesian and Mediterranean floras: Molecular evidence for multiple colonizations into Macaronesia and back-colonization of the continent in Convolvulus (Convolvulaceae). American Journal of Botany 91: 1070-1085.

Carracedo, J.C. \& Day, S. 2002. Canary Islands: Classic Geology in Europe 4. Terra Publishing, Harpenden, Herts.

Castro Parga, I., Moreno Saiz, J.C., Humphries, C.J. \& Williams, P.H. 1996. Strengthening the Natural and National Park system of Iberia to conserve vascular plants. Botanical Journal of the Linnean Society, 121: 189-206.

Coello, J., Cantagrel, J.M., Hernán, F., Fúster, J.M., Ibarrola, E., Ancochea, E., Casquet, C., Jamond, C., Díaz de Terán, J.-R. \& Cendrero, A. 1992. Evolution of the eastern volcanic ridge of the Canary Islands based on new K-Ar data. J. Volcanol. Geotherm. Res. 53: 251-274.

de-Klerk, H.M., Fjeldså, J. Blyth, S. \& Burgués, N.D. 2004. Gaps in the protected area network for threatened Afrotropical birds. Biological Conservation 117: 529-537.

del-Arco, M., Acebes, J.R., Pérez-de-Paz, P.L. \& Marrero, M.C. 1999. Bioclimatology and climatophilous vegetation of Hierro (part 2) and La Palma (Canary Islands). Phytocoenologia 29(2): 253-290.

del-Arco, M., Salas, M., Acebes, J.R., Marrero, M.C., Reyes-Betancort, J.A. \& Pérez de Paz 2002. Bioclimatology and climatophilous vegetation of Gran Canaria (Canary Islands). Annales Botanici Fennici 39: 15-41.

del-Arco, M., Pérez-de-Paz, P.L., Acebes, J.R., González-Mancebo, J.M., Reyes-Betancort, J.A., Bermejo, J.A., de-Armas, S. \& González, R. 2006. Bioclimatology and climatophilous vegetation of Tenerife (Canary Islands). Annales Botanici Fennici 43: 167-192.
del-Valle, E., Maldonaldo, J., Sainz, H. \& Sánchez de Dios, R. 2004. Áreas importantes para la flora amenazada española. In: Bañares, Á. \& al. (eds.), Atlas y Libro Rojo de la flora vascular amenazada de España: 979-1007. Madrid.

Downie, S.R., Katz-Downie, D.S. \& Watson, M.F. 2000. A phylogeny of the flowering plant family Apiaceae based on chloroplast DNA rpl16 and rpoC1 intron sequences: Towards a suprageneric classification of subfamily apioideae. American Journal of Botany 87: 273-292.

Emerson, B.C. \& Kolm, N. 2005. Species diversity can drive speciation. Nature 434: 1015-1017.

Faith, D.P. 1992. Conservation evaluation and phylogenetic diversity. Biological Conservation 61: 1-10.

Fior, S., Karis, P.O., Casazza, G., Minuto, L. \& Sala, F. 2006. Molecular phylogeny of the Caryophyllaceae (Caryophyllales) inferred from chloroplast matK and nuclear rDNA ITS sequences. American Journal of Botany 93: 399-411.

Forest, F., Grenyer, R., Rouget, M., Davies, T.J., Cowling, R.M., Faith, D.P., Balmford, A., Manning, J.C., Procheş, Ş., van der Bank, M., Reeves, G., Hedderson, T.A.J \& Savolainen, V. 2007. Preserving the evolutionary potential of floras in biodiversity hotspots. Nature 445: 757-760.

Francisco-Ortega, J., Barber, J.C., Santos-Guerra, A., Febles-Hernandez, R. \& Cansen, R.K. 2001. Origin and evolution of the endemic genera of Gonosperminae (Asteraceae: Anthemideae) from the Canary Islands: evidence from nucleotide sequences of the internal transcribed spacers of the nuclear ribosomal DNA. American Journal of Botany 88: 161-169.

Gaisberg, M. von \& Stierstorfer, C. 2005. The significance of ecological traits for the speciation of endemic angiosperms on $\mathrm{El}$ Hierro (Canary Islands). Phytocoenologia 35: 39-52.

Gobierno de Canarias. 2000. Decreto Legislativo 1/2000, de 8 de mayo, por el que se aprueba el Texto Refundido de las Leyes de Ordenación del Territorio de Canarias y de Espacios Naturales de Canarias. Boletín Oficial de Canarias 60: 5989-6307.

Gobierno de Canarias. 2001. Decreto 151/2001, de 23 de julio, por el que se crea el Catálogo de Especies Amenazadas de Canarias. Boletin Oficial de Canarias 97: 11101-11111.

Gómez Campo, C. 1996. Libro Rojo de especies vegetales amenazadas de las Islas Canarias. Gobierno de Canarias.

Grass Phylogeny Working Group. 2001. Phylogeny and subfamilial classification of the grasses (Poaceae). Annals of the Missouri Botanical Garden 88: 373-457.

Guillou, H., Carracedo, J.C., Pérez Torrado, F.J. \& Rodríguez Badiola, E. 1996. K-Ar ages and magnetic stratigraphy of a hotspot-induced, fast grown oceanic island: El Hierro, Canary Islands. Journal of Volcanology and Geothermal Research 78: 239-250.

Harley, R.M., Atkins, S., Budantsev, A.L., Cantino, P.D., Conn, B.J., Grayer, R., Harley, M.M., de Kok, R., Krestovskaja, T., Morales, R., Paton, A.J., Ryding, O. \& Upson, T. 2004. Labiatae. In: Kadereit, J.W. (ed.), The families and genera of vascular plants, Vol. VII, Lamiales: 167-282. Berlin.

Helfgott, D.M., Francisco-Ortega, J., Santos-Guerra, A., Jansen, R.K. \& Simpson, B.B. 2000. Biogeography and breeding system evolution of the woody Bencomia alliance (Rosaceae) in Macaronesia based on ITS sequence data. Systematic Botany 25: 82-97.

Hulbert, A.H. \& Jetz, W. 2007. Species richness, hotspots and scale dependence of range maps in ecology and conservation. Proceedings of the Nacional Academy of Sciences of the United States of America 104: 13384-13389. 
Humphries, C.J. 1979. Endemism and evolution in Macaronesia. In: Bramwell, D. (ed.), Plants and Islands: 171-200. London.

Humphries, C., Araujo, M., Williams, P., Lampinen, R., Lahti, T. \& Uotila, P. 1999. Plant diversity in Europe: Atlas Florae Europaeae and WORLDMAP. Acta Botanica Fennica 162: 11-21.

Kadereit, G., Borsch, T., Weising, K. \& Freitag, H. 2003. Phylogeny of Amaranthaceae and Chenopodiaceae and the Evolution of C4 Photosynthesis. International Journal of Plant Sciences 164: 959-986

Kim, S.-Ch., Crawford, D.J., Francisco-Ortega, J. \& SantosGuerra, A.. 1996. A common origin for woody Sonchus and five related genera in the Macaronesian islands: Molecular evidence for extensive radiation. Proceedings of the Nacional Academy of Sciences of the United States of America 93: 77437748.

Lamoreux, J.F., Morrison, J.C., Ricketts, T.H., Olson, D.M., Dinerstein, E., McKnight, M.W. \& Shugart, H.H. 2006. Global tests of biodiversity concordance and the importance of endemism. Nature 440: 212-214.

Langhammer, P.F., Bakarr, M.I., Bennun, L.A., Brooks, T.M., Clay, R.P., Darwall, W., Silva, N. de, Edgar, G.J., Eken, G., Fishpool, L.D.C., Fonseca, G.A.B. da, Foster, M.N., Knox, D.H., Matiku, P., Radford, E.A., Salaman, P., Sechrest, W. \& Tordoff, A.W. 2007. Identification and gap analysis of key biodiversity areas: targets for comprehensive protected area systems. Gland.

Lewis, B., Schrire, B. Mackinder \& Lock, M. (eds). 2005. Legumes of the World. London.

Lledó, M.L., Crespo, M.P., Fay, M.F. \& Chase, M.W. 2005. Molecular phylogenetics of Limonium and related genera (Plumbaginaceae): biogeographical and systematic implications. American Journal of Botany 92: 1189-1198.

Mort, M.E., Soltis, D.E., Soltis, P.S., Francisco-Ortega, J. \& Santos-Guerra, A. 2002. Phylogenetics and evolution of the Macaronesian clade of Crassulaceae inferred from nuclear and chloroplast sequence data. Systematic Botany 27: 271288.

Orme, C.D.L., Davies, R.G., Burgess, M., Eigenbrod, F., Pickup, N., Olson, V.A., Webster, A.J., Ding, T-S., Rasmussen, P.C., Ridgely, R.S., Stattersfield, A.J., Bennett, P.M., Blackburn, T.M., Gaston, K.J. \& Owens, I.P.F. 2005. Global hotspots of species richness are not congruent with endemism or threat. Nature 436: 1016-1019.

Panero, J.L., Francisco-Ortega, J., Jansen, R.K. \& Santos-Guerra, A. 1999. Molecular evidence for multiple origins of woodiness and a New World biogeographic connection of the Macaronesian Island endemic Pericallis (Asteraceae: Senecioneae). Proceedings of the Nacional Academy of Sciences of the United States of America 96: 13886-13891.

Pereira, H.M., Vânia, M.P. \& Vicente, L. 2007. Does species diversity really drive speciation? Ecography 30: 328-330.

Polasky, S., Csuti, B., Vossler, C.A. \& Meyers, S.M. 2001. A comparison of taxonomic distinctiveness versus richness as criteria for setting conservation priorities for North American birds. Biological Conservation 97: 99-105.

Quézel, P. \& Medail, F. 1995. La région circuí-méditerranéene, centre mundial majeur de biodiversité végétale. In: Actes des $G^{\text {imes }}$ rencontres de l'Agence Régionale pour l'Environment, Provence-Alpes-Côte d'Azur: 152-160. Gap.
Reyes-Betancort, J.A., Wildpret, W. \& León Arencibia, M.C. 1998. El paisaje vegetal de Lanzarote a partir de fuentes escritas (siglos XV-XX). Anuario del Instituto de Estudios Canarios 43: 31-54.

Reyes-Betancort, J.A., Wildpret, W. \& León Arencibia, M.C. 2001. The vegetation of Lanzarote (Canary Islands). Phytocoenologia 31(2): 185-247.

Rivas-Martínez, S. 2007. Mapas de series, geoseries y geopermaseries de vegetación de España [Memoria del mapa de vegetación potencial de España], Parte I. Itinera Geobotánica 17: $1-435$.

Rodrigues, A.S.L. \& Gaston, K.J. 2001. How large do reserve networks need to be? Ecology Letters 4: 602-609.

Rodríguez Delgado, O. 2005. El Paisaje Vegetal. In: Rodríguez Delgado (ed.), Patrimonio Natural de la Isla de Fuerteventura. Excmo. Cabildo de Fuerteventura, Gobierno de Canarias y Centro de la Cultura Popular Canaria.

Rodríguez Delgado, O., García Gallo, A. \& Reyes-Betancort, J.A. 2000. Estudio fitosociológico de la vegetación actual de la isla de Fuerteventura. Vieraea 28: 61-98.

Santos Guerra, A. 2001. Flora vascular nativa. In: Fernández-Palacios, J.M. \& Martín Esquivel, J.L., Naturaleza de las Islas Canarias, Ecología y Conservación: 185-192. Santa Cruz de Tenerife.

Stierstorfer, C. \& Gaisberg, M. von. 2006. Annotated checklist and distribution of the vascular plants of El Hierro, Canary Islands, Spain. Englera 27: 1-221.

Suárez, C. 1994. Estudio de los relictos actuales del monte verde en Gran Canaria. Cabildo Insular de Gran Canaria. Las Palmas de Gran Canaria.

Sundseth, K. 2005. Natura 2000 in the Macaronesian region. Luxembourg.

Susanna, A., Garnatje, T. \& García-Jacas, N. 1999. Molecular phylogeny of Cheirolophus (Asteraceae: Cardueae-Centaureinae) based on ITS sequences of nuclear ribosomal DNA. Plant Systematics and Evolution 214: 147-160.

Trusty, J.L. Olmstead, R.G., Santos Guerra, A., Sá-Fontinha, S. \& Francisco-Ortega, J. 2005. A chloroplast and nuclear DNA based phylogeny of the Macaronesian endemic genus Bystropogon L'Her. (Lamiaceae): paleoislands, ecological shifts and inter-island colonizations. Molecular Ecology 14: 1177-1189.

Vane-Wright, R.I., Humphries, C.J. \& Williams, P.H. 1991. What to protect?-Systematics and the agony of choice. Biological Conservation 55: 235-254.

Väre, H., Lampinen, R., Humphries, C. \& Williams, P. 2003. Taxonomic diversity of vascular plants in the European alpine areas. In: Nagy, L. \& al. (eds.), Alpine Biodiversity in Europe: 133148. Berlin.

Whittaker, R.J., Ladle, R.J., Araújo, M.B., Fernández-Palacios, J.M., Domingo Delgado J. \& Arévalo J.R. 2007. The island immaturity-speciation pulse model of island evolution: an alternative to the "diversity begets diversity" model. Ecography 30: 321-327.

Williams, P.H., Prance, G.T., Humphries, C.J. \& Edwards, K.S. 1996. Promise and problems in applying quantitative complementary areas for representing the diversity of some Neotropical plants (families Dichapetalaceae, Lecythidaceae, Caryocaraceae, Chrysobalanaceae and Proteaceae). Biological Journal of the Linnean Society 58: 125-157.

Williams, P.H. 2003. WORLDMAP version 4.20.24. Biogeography and Conservation Lab, The Natural History Museum, Cromwell Road. London. 


\section{Appendix 1}

Classification codes for generic-level phylogenetic classification of Canary Island endemic taxa used to determine Phylogenetic Diversity (PD). For genera represented in the Canary Islands by two or more groups resulting from independent colonisation events, each colonisation group is scored separately and is indicated in the table below by a roman numeral suffix (e.g. Limonium I, Limonium II and Limonium III for the three distinct Limonium groups in the archipelago).

\begin{tabular}{|c|c|c|c|}
\hline Classification code & Taxon & Order & Family \\
\hline 1.1 & Juniperus & Pinales & Cupressaceae \\
\hline 1.2 & Pinus & Pinales & Pinaceae \\
\hline 2.1 & Apollonias & Laurales & Lauraceae \\
\hline 2.2.1.1.1 & Arum & Alismatales & Araceae \\
\hline 2.2.1.1.2 & Dracunculus & Alismatales & Araceae \\
\hline 2.2.1.2.1 & Androcymbium & Liliales & Colchicaceae \\
\hline 2.2.1.2.2.1.1.1 & Orchis & Asparagales & Orchidaceae \\
\hline 2.2.1.2.2.1.1.2 & Hymantoglossum & Asparagales & Orchidaceae \\
\hline 2.2.1.2.2.1.1.3 & Serapias & Asparagales & Orchidaceae \\
\hline 2.2.1.2.2.1.2.1 & Scilla & Asparagales & Hyacinthaceae \\
\hline 2.2.1.2.2.1.2.2.1 & Asparagus & Asparagales & Asparagaceae \\
\hline 2.2.1.2.2.1.2.2.2.1 & Dracaena & Asparagales & Ruscaceae \\
\hline 2.2.1.2.2.1.2.2.2.2 & Semele & Asparagales & Ruscaceae \\
\hline 2.2.1.2.2.2.1 & Phoenix & Arecales & Arecaceae \\
\hline 2.2.1.2.2.2.2.1.1 & Carex & Poales & Cyperaceae \\
\hline 2.2.1.2.2.2.2.1.2 & Luzula & Poales & Juncaceae \\
\hline 2.2.1.2.2.2.2.2.1 & Dactylis & Poales & Poaceae \\
\hline 2.2.1.2.2.2.2.2.2 & Brachypodium & Poales & Poaceae \\
\hline 2.2.1.2.2.2.2.2.3 & Festuca & Poales & Poaceae \\
\hline 2.2.1.2.2.2.2.2.4 & Holcus & Poales & Poaceae \\
\hline 2.2.1.2.2.2.2.2.5 & Lolium & Poales & Poaceae \\
\hline 2.2.1.2.2.2.2.2.5 & Arrbenatherum & Poales & Poaceae \\
\hline 2.2.2.1.1.1.1 & Bosea & Caryophyllales & Amaranthaceae \\
\hline 2.2.2.1.1.1.2.1 & Patellifolia & Caryophyllales & Amaranthaceae \\
\hline 2.2.2.1.1.1.2.2 & Salsola & Caryophyllales & Amaranthaceae \\
\hline 2.2 .2 .1 .1 .2 .1 & Minuartia & Caryophyllales & Caryophyllaceae \\
\hline 2.2.2.1.1.2.2 & Cerastium & Caryophyllales & Caryophyllaceae \\
\hline 2.2.2.1.1.2.3 & Silene & Caryophyllales & Caryophyllaceae \\
\hline 2.2.2.1.1.2.4 & Herniaria & Caryophyllales & Caryophyllaceae \\
\hline 2.2.2.1.1.2.5 & Polycarpaea & Caryophyllales & Caryophyllaceae \\
\hline 2.2.2.1.1.2.6 & Dicherantbus & Caryophyllales & Caryophyllaceae \\
\hline 2.2.2.1.1.2.7 & Paronychia & Caryophyllales & Caryophyllaceae \\
\hline 2.2.2.1.2.1.1.1 & Limonium I & Caryophyllales & Plumbaginaceae \\
\hline 2.2.2.1.2.1.1.2 & Limonium II & Caryophyllales & Plumbaginaceae \\
\hline 2.2.2.1.2.1.1.3 & Limonium III & Caryophyllales & Plumbaginaceae \\
\hline 2.2.2.1.2.2 & Rumex & Caryophyllales & Polygonaceae \\
\hline 2.2 .2 .2 & Kunkeliella & Santalales & Santalaceae \\
\hline
\end{tabular}




\begin{tabular}{|c|c|c|c|}
\hline Classification code & Taxon & Order & Family \\
\hline 2.2.2.3.1.1 & Sedum & Saxifragales & Crassulaceae \\
\hline 2.2 .2 .3 .1 .2 .1 & Aichryson & Saxifragales & Crassulaceae \\
\hline 2.2 .2 .3 .1 .2 .2 .1 & Monanthes & Saxifragales & Crassulaceae \\
\hline 2.2.2.3.1.2.2.2 & Aeonium & Saxifragales & Crassulaceae \\
\hline 2.2 .2 .3 .1 .2 .2 .2 & Greenovia & Saxifragales & Crassulaceae \\
\hline 2.2 .2 .3 .2 .1 & Geranium & Geraniales & Geraniaceae \\
\hline 2.2.2.3.2.2.1 & Maytenus & Celastrales & Celastraceae \\
\hline 2.2.2.3.2.2.2.1.1 & Euphorbia I & Malphigiales & Euphorbiaceae \\
\hline 2.2.2.3.2.2.2.1.2 & Euphorbia II & Malphigiales & Euphorbiaceae \\
\hline 2.2.2.3.2.2.2.1.3 & Euphorbia III & Malphigiales & Euphorbiaceae \\
\hline 2.2.2.3.2.2.2.2 & Hypericum & Malphigiales & Hypericaceae \\
\hline 2.2.2.3.2.2.2.3 & Viola & Malphigiales & Violaceae \\
\hline 2.2.2.3.2.2.3.1.1.1.1 & Dorycnium & Fabales & Fabaceae \\
\hline 2.2.2.3.2.2.3.1.1.1.2 & Lotus & Fabales & Fabaceae \\
\hline 2.2.2.3.2.2.3.1.1.2.1 & Cicer & Fabales & Fabaceae \\
\hline 2.2 .2 .3 .2 .2 .3 .1 .1 .2 .2 .1 & Vicia & Fabales & Fabaceae \\
\hline 2.2 .2 .3 .2 .2 .3 .1 .1 .2 .2 .2 & Ononis & Fabales & Fabaceae \\
\hline 2.2 .2 .3 .2 .2 .3 .1 .2 .1 & Anagyris & Fabales & Fabaceae \\
\hline 2.2.2.3.2.2.3.1.2.2.1 & Adenocarpus & Fabales & Fabaceae \\
\hline 2.2 .2 .3 .2 .2 .3 .1 .2 .2 .2 .1 & Chamaecytisus & Fabales & Fabaceae \\
\hline 2.2.2.3.2.2.3.1.2.2.2.1 & Spartocytisus & Fabales & Fabaceae \\
\hline 2.2.2.3.2.2.3.1.2.2.2.2.1.1 & Teline I & Fabales & Fabaceae \\
\hline 2.2.2.3.2.2.3.1.2.2.2.2.1.2 & Teline II & Fabales & Fabaceae \\
\hline 2.2.2.3.2.2.3.1.2.2.2.2.1.3 & Genista & Fabales & Fabaceae \\
\hline 2.2 .2 .3 .2 .2 .3 .1 .2 .2 .2 .2 .2 & Retama & Fabales & Fabaceae \\
\hline 2.2 .2 .3 .2 .2 .3 .2 .1 .2 .1 & Rhamnus & Rosales & Rhamnaceae \\
\hline 2.2 .2 .3 .2 .2 .3 .2 .1 .2 .2 .1 & Gesnouinia & Rosales & Urticaceae \\
\hline 2.2.2.3.2.2.3.2.1.2.2.2 & Parietaria & Rosales & Urticaceae \\
\hline 2.2.2.3.2.2.3.2.2.1 & Bencomia & Rosales & Rosaceae \\
\hline 2.2 .2 .3 .2 .2 .3 .2 .2 .2 & Dendriopoterium & Rosales & Rosaceae \\
\hline 2.2 .2 .3 .2 .2 .3 .2 .2 .3 & Marcetella & Rosales & Rosaceae \\
\hline 2.2 .2 .3 .2 .2 .3 .3 .1 & Bryonia & Cucurbitales & Cucurbitaceae \\
\hline 2.2.2.3.2.2.3.3.1 & Myrica & Fagales & Myicaceae \\
\hline 2.2.2.3.2.3.1.1.1.1 & Matthiola & Brassicales & Brassicaceae \\
\hline 2.2.2.3.2.3.1.1.1.2 & Parolinia & Brassicales & Brassicaceae \\
\hline 2.2 .2 .3 .2 .3 .1 .1 .2 .1 & Crambe & Brassicales & Brassicaceae \\
\hline 2.2.2.3.2.3.1.1.2.2 & Brassica & Brassicales & Brassicaceae \\
\hline 2.2 .2 .3 .2 .3 .1 .1 .3 & Lobularia & Brassicales & Brassicaceae \\
\hline 2.2.2.3.2.3.1.1.4.1 & Erysimum & Brassicales & Brassicaceae \\
\hline 2.2 .2 .3 .2 .3 .1 .1 .4 .2 & Descurainia & Brassicales & Brassicaceae \\
\hline 2.2 .2 .3 .2 .3 .1 .2 & Reseda & Brassicales & Resedaceae \\
\hline 2.2.2.3.2.3.2.1.1.1 & Helianthemum & Malvales & Cistaceae \\
\hline 2.2 .2 .3 .2 .3 .2 .1 .1 .2 & Cistus & Malvales & Cistaceae \\
\hline
\end{tabular}




\begin{tabular}{|c|c|c|c|}
\hline Classification code & Taxon & Order & Family \\
\hline $2 \cdot 2 \cdot 2 \cdot 3 \cdot 2 \cdot 3 \cdot 2 \cdot 1.2$ & Navea & Malvales & Malvaceae \\
\hline 2.2.2.3.2.3.2.1.2 & Lavatera & Malvales & Malvaceae \\
\hline 2.2 .2 .3 .2 .3 .2 .2 .1 & Neochamaelea & Sapindales & Rutaceae \\
\hline $2.2 .2 \cdot 3 \cdot 2 \cdot 3 \cdot 2.2 .2$ & Ruta & Sapindales & Rutaceae \\
\hline 2.2.2.4.1.1 & Pleiomeris & Ericales & Myrsinaceae \\
\hline 2.2.2.4.1.2.1 & Arbutus & Ericales & Ericaceae \\
\hline 2.2 .2 .4 .1 .2 .2 & Erica & Ericales & Ericaceae \\
\hline 2.2.2.4.2.1.1 & Echium & Unplaced Euasterid I & Boraginaceae \\
\hline 2.2 .2 .4 .2 .1 .2 .1 .1 .1 & Pbyllis & Gentianales & Rubiaceae \\
\hline 2.2.2.4.2.1.2.1.1.2 & Plocama & Gentianales & Rubiaceae \\
\hline 2.2.2.4.2.1.2.1.2.1 & Ixantbus & Gentianales & Gentianaceae \\
\hline 2.2.2.4.2.1.2.1.2.2.1 & Ceropegia & Gentianales & Apocynaceae \\
\hline 2.2.2.4.2.1.2.1.2.2.2 & Caralluma & Gentianales & Apocynaceae \\
\hline 2.2.2.4.2.1.2.2.1.1 & Olea & Lamiales & Oleaceae \\
\hline 2.2.2.4.2.1.2.2.1.2.1 & Justicia & Lamiales & Acanthaceae \\
\hline 2.2.2.4.2.1.2.2.1.2.2.1 & Kickxia & Lamiales & Plantaginaceae \\
\hline 2.2.2.4.2.1.2.2.1.2.2.2.1.1 & Isoplexis & Lamiales & Plantaginaceae \\
\hline 2.2 .2 .4 .2 .1 .2 .2 .1 .2 .2 .2 .1 .2 & Plantago & Lamiales & Plantaginaceae \\
\hline 2.2 .2 .4 .2 .1 .2 .2 .1 .2 .2 .2 .2 .1 & Globularia & Lamiales & Plantaginaceae \\
\hline 2.2.2.4.2.1.2.2.1.2.2.2.2.2 & Campylanthus & Lamiales & Plantaginaceae \\
\hline $2.2 .2 .4 \cdot 2.1 \cdot 2 \cdot 2.1 .2 .3 .1$ & Camptoloma & Lamiales & Scrophulariaceae \\
\hline 2.2.2.4.2.1.2.2.1.2.3.2 & Scropbularia & Lamiales & Scrophulariaceae \\
\hline 2.2.2.4.2.1.2.2.1.2.4.1 & Teucrium & Lamiales & Lamiaceae \\
\hline 2.2.2.4.2.1.2.2.1.2.4.2.1 & Sideritis & Lamiales & Lamiaceae \\
\hline 2.2.2.4.2.1.2.2.1.2.4.2.2.1.1 & Salvia & Lamiales & Lamiaceae \\
\hline 2.2.2.4.2.1.2.2.1.2.4.2.2.1.2 & Nepeta & Lamiales & Lamiaceae \\
\hline 2.2.2.4.2.1.2.2.1.2.4.2.2.1.3 & Bystropogon & Lamiales & Lamiaceae \\
\hline 2.2.2.4.2.1.2.2.1.2.4.2.2.1.4 & Thymus & Lamiales & Lamiaceae \\
\hline 2.2.2.4.2.1.2.2.1.2.4.2.2.1.5 & Micromeria & Lamiales & Lamiaceae \\
\hline $2.2 .2 .4 .2 .1 .2 .2 .1 \cdot 2 \cdot 4.2 .2 .2$ & Lavandula & Lamiales & Lamiaceae \\
\hline $2 \cdot 2 \cdot 2 \cdot 4 \cdot 2 \cdot 1 \cdot 2 \cdot 2 \cdot 1 \cdot 2.5$ & Odontites & Lamiales & Orobanchaceae \\
\hline 2.2.2.4.2.1.2.2.2.1.1 & Convolvulus I & Solanales & Convolvulaceae \\
\hline 2.2.2.4.2.1.2.2.2.1.2 & Convolvulus II & Solanales & Convolvulaceae \\
\hline 2.2.2.4.2.1.2.2.2.2.1.1 & Normania & Solanales & Solanaceae \\
\hline 2.2 .2 .4 .2 .1 .2 .2 .2 .2 .1 .2 & Solanum & Solanales & Solanaceae \\
\hline 2.2.2.4.2.1.2.2.2.2.2 & Whitania & Solanales & Solanaceae \\
\hline $2 \cdot 2 \cdot 2 \cdot 4 \cdot 2 \cdot 2.1$ & Ilex & Aquifoliales & Aquifoliaceae \\
\hline 2.2.2.4.2.2.2.1 & Rutheopsis & Apiales & Apiaceae \\
\hline $2.2 .2 .4 \cdot 2 \cdot 2 \cdot 2 \cdot 1.1$ & Bupleurum & Apiales & Apiaceae \\
\hline 2.2.2.4.2.2.2.1.2.1 & Cryptotaenia & Apiales & Apiaceae \\
\hline 2.2.2.4.2.2.2.1.2.2.1 & Ammodaucus & Apiales & Apiaceae \\
\hline 2.2.2.4.2.2.2.1.2.2.2.1 & Pimpinella & Apiales & Apiaceae \\
\hline 2.2.2.4.2.2.2.1.2.2.2.2.1 & Seseli & Apiales & Apiaceae \\
\hline
\end{tabular}




\begin{tabular}{|c|c|c|c|}
\hline Classification code & Taxon & Order & Family \\
\hline 2.2.2.4.2.2.2.1.2.2.2.2.2 & Ferula & Apiales & Apiaceae \\
\hline 2.2 .2 .4 .2 .2 .2 .2 .1 & Canarina & Asterales & Campanulaceae \\
\hline 2.2.2.4.2.2.2.2.2.1.1.1 & Atractylis & Asterales & Asteraceae \\
\hline 2.2.2.4.2.2.2.2.2.1.1.2 & Carlina & Asterales & Asteraceae \\
\hline 2.2.2.4.2.2.2.2.2.1.2.1 & Onopordon & Asterales & Asteraceae \\
\hline 2.2.2.4.2.2.2.2.2.1.2.2.1 & Carduus & Asterales & Asteraceae \\
\hline 2.2.2.4.2.2.2.2.2.1.2.2.1 & Volutaria & Asterales & Asteraceae \\
\hline 2.2.2.4.2.2.2.2.2.1.2.2.2.2 & Stemmacantha & Asterales & Asteraceae \\
\hline 2.2.2.4.2.2.2.2.2.1.2.2.2.3 & Cheirolophus & Asterales & Asteraceae \\
\hline 2.2.2.4.2.2.2.2.2.2.1.1 & Crepis & Asterales & Asteraceae \\
\hline 2.2.2.4.2.2.2.2.2.2.1.2 & Hypochoeris & Asterales & Asteraceae \\
\hline 2.2.2.4.2.2.2.2.2.2.1.3.1 & Tolpis & Asterales & Asteraceae \\
\hline 2.2.2.4.2.2.2.2.2.2.1.3.2 & Andryala & Asterales & Asteraceae \\
\hline 2.2.2.4.2.2.2.2.2.2.1.4.1 & Reichardia & Asterales & Asteraceae \\
\hline 2.2.2.4.2.2.2.2.2.2.1.4.2.1 & Lactucosonchus & Asterales & Asteraceae \\
\hline 2.2.2.4.2.2.2.2.2.2.1.4.2.2 & Chrysoprenanthes & Asterales & Asteraceae \\
\hline 2.2.2.4.2.2.2.2.2.2.1.4.2.2 & Prenanthes & Asterales & Asteraceae \\
\hline 2.2.2.4.2.2.2.2.2.2.1.4.2.2 & Sonchus & Asterales & Asteraceae \\
\hline 2.2.2.4.2.2.2.2.2.2.1.4.2.2 & Sventenia & Asterales & Asteraceae \\
\hline 2.2.2.4.2.2.2.2.2.2.1.4.2.2 & Taeckholmia & Asterales & Asteraceae \\
\hline 2.2.2.4.2.2.2.2.2.2.1.5 & Lactuca & Asterales & Asteraceae \\
\hline 2.2.2.4.2.2.2.2.2.2.2.1.1.1 & Asteriscus I & Asterales & Asteraceae \\
\hline 2.2.2.4.2.2.2.2.2.2.2.1.1.2 & Asteriscus II & Asterales & Asteraceae \\
\hline 2.2 .2 .4 .2 .2 .2 .2 .2 .2 .2 .1 .2 .1 & Allagopappus & Asterales & Asteraceae \\
\hline 2.2.2.4.2.2.2.2.2.2.2.1.2.2.1 & Vieria & Asterales & Asteraceae \\
\hline 2.2.2.4.2.2.2.2.2.2.2.1.2.2.2 & Schizogyne & Asterales & Asteraceae \\
\hline 2.2.2.4.2.2.2.2.2.2.2.1.2.2.3 & Pulicaria & Asterales & Asteraceae \\
\hline 2.2 .2 .4 .2 .2 .2 .2 .2 .2 .2 .2 .1 .1 & Gnaphalium & Asterales & Asteraceae \\
\hline 2.2.2.4.2.2.2.2.2.2.2.2.1.2 & Phagnalon & Asterales & Asteraceae \\
\hline 2.2.2.4.2.2.2.2.2.2.2.2.1.3 & Helichrysum & Asterales & Asteraceae \\
\hline 2.2 .2 .4 .2 .2 .2 .2 .2 .2 .2 .2 .2 .1 & Erigeron & Asterales & Asteraceae \\
\hline 2.2.2.4.2.2.2.2.2.2.2.2.2.2.1 & Artemisia & Asterales & Asteraceae \\
\hline 2.2.2.4.2.2.2.2.2.2.2.2.2.2.2 & Argyranthemum & Asterales & Asteraceae \\
\hline 2.2 .2 .4 .2 .2 .2 .2 .2 .2 .2 .2 .2 .2 .3 & Gonospermum & Asterales & Asteraceae \\
\hline 2.2 .2 .4 .2 .2 .2 .2 .2 .2 .2 .2 .2 .3 .1 & Senecio & Asterales & Asteraceae \\
\hline 2.2.2.4.2.2.2.2.2.2.2.2.2.3.2 & Pericallis & Asterales & Asteraceae \\
\hline $2 \cdot 2 \cdot 2 \cdot 4 \cdot 2 \cdot 2 \cdot 3.1$ & Sambucus & Dipsacales & Caprifoliaceae \\
\hline $2.2 .2 \cdot 4 \cdot 2 \cdot 2 \cdot 3.2$ & Pterocephalus & Dipsacales & Dipsacaeae \\
\hline
\end{tabular}

